\title{
Mercury Isotope Fractionation by Internal Demethylation and Biomineralization Reactions in Seabirds: Implications for Environmental Mercury Science
}

\author{
Alain Manceau, ${ }^{1, *}$ Romain Brossier, ${ }^{1}$ Sarah E. Janssen, ${ }^{2}$ Tylor J. Rosera, ${ }^{2}$ David P. Krabbenhoft, ${ }^{2}$ \\ Yves Cherel, ${ }^{3}$ Paco Bustamante, ${ }^{4}$ and Brett A. Poulin ${ }^{5, *}$ \\ ${ }^{1}$ Université Grenoble Alpes, ISTerre, CNRS, 38000 Grenoble, France \\ ${ }^{2}$ U.S. Geological Survey, Upper Midwest Water Science Center, Middleton, WI, 53562, USA \\ ${ }^{3}$ Centre d'Etudes Biologiques de Chizé (CEBC), CNRS, La Rochelle Université, 79360 Villiers-en- \\ Bois, France \\ ${ }^{4}$ Littoral Environnement et Sociétés (LIENSs), CNRS-La Rochelle Université, 17000 La Rochelle, \\ France \\ ${ }^{5}$ Department of Environmental Toxicology, University of California Davis, Davis, CA 95616, \\ USA
}

* Corresponding authors. alain.manceau@univ-grenoble-alpes.fr; $\underline{\text { bapoulin@ucdavis.edu }}$

\section{Keywords}

Mercury, isotope fractionation, toxicology, bird

\begin{abstract}
A prerequisite for environmental and toxicological applications of mercury (Hg) stable isotopes in wildlife and humans is quantifying the isotopic fractionation of biological reactions. Here, we measured stable $\mathrm{Hg}$ isotope values of relevant tissues of giant petrels (Macronectes spp.). Isotopic data were interpreted with published HR-XANES spectroscopic data that document a step-wise transformation of methylmercury $(\mathrm{MeHg})$ to $\mathrm{Hg}$-tetraselenolate $\left(\mathrm{Hg}(\mathrm{Sec})_{4}\right)$ and mercury selenide $(\mathrm{HgSe})(\mathrm{Sec}=$ selenocysteine $)$. By mathematical inversion of isotopic and spectroscopic data, identical $\delta^{202} \mathrm{Hg}$ values for $\mathrm{MeHg}(2.69 \pm 0.04 \%$ \%, $\mathrm{Hg}(\mathrm{Sec}) 4(-1.37 \pm 0.06 \%$ ) , and $\mathrm{HgSe}(0.18 \pm 0.02 \%$ ) were determined in 23 tissues of eight birds from the Kerguelen Islands and Adélie Land (Antarctica). Isotopic differences in $\delta^{202} \mathrm{Hg}$ between $\mathrm{MeHg}$ and $\mathrm{Hg}(\mathrm{Sec})_{4}(-4.1 \pm 0.1 \%$ ) reflect mass-dependent fractionation from a kinetic isotope effect due to the $\mathrm{MeHg} \rightarrow \mathrm{Hg}(\mathrm{Sec})_{4}$ demethylation reaction. Surprisingly, $\mathrm{Hg}(\mathrm{Sec})_{4}$ and $\mathrm{HgSe}$ differed isotopically in $\delta^{202} \mathrm{Hg}(+1.6 \pm 0.1 \%$ o $)$ and mass-independent anomalies (i.e., changes in $\Delta^{199} \mathrm{Hg}$ of $\leq 0.3 \%$ ), consistent with equilibrium isotope effects of massdependent and nuclear volume fractionation from $\mathrm{Hg}(\mathrm{Sec})_{4} \rightarrow \mathrm{HgSe}$ biomineralization. The invariance of species-specific $\delta^{202} \mathrm{Hg}$ values across tissues and individual birds reflects the kinetic lability of $\mathrm{Hg}$ ligand bonds and tissue-specific redistribution of $\mathrm{MeHg}$ and inorganic $\mathrm{Hg}$, likely as $\mathrm{Hg}(\mathrm{Sec})_{4}$. These observations provide fundamental information necessary to improve the interpretation of stable $\mathrm{Hg}$ isotope data and provoke a revisitation of processes governing isotopic fractionation in biota and toxicological risk assessment in wildlife.
\end{abstract}

\section{INTRODUCTION}

The efficient biomagnification of methylmercury $(\mathrm{MeHg})$ in aquatic food webs results in elevated dietary exposure of mercury $(\mathrm{Hg})$ to top predators such as seabirds and marine mammals. ${ }^{1}$ After the 
assimilation of dietary $\mathrm{MeHg}$ in the digestive tract, $\mathrm{MeHg}$ is circulated in the bloodstream to various tissues and organs (e.g., brain) and forms MeHg-cysteine (MeHg-Cys) complexes with proteins. ${ }^{2}$ At the organism level the toxicological effects of $\mathrm{MeHg}$ are controlled, in part, by two central processes: the demethylation of $\mathrm{MeHg}$ within cells and the internal exchange and depuration of both $\mathrm{MeHg}$ and inorganic $\mathrm{Hg}$ degradation products. The biomineralization of $\mathrm{MeHg}$ to $\mathrm{HgSe}$ granules is accepted as an important internal transformation of $\mathrm{Hg}$ in vertebrates, ${ }^{3,4}$ but until recently little was known on the biochemistry of the reaction. Development and application of new analytical approaches, most notably high energy-resolution X-ray absorption near-edge structure (HR-XANES) spectroscopy, identified that $\mathrm{MeHg}$ is first demethylated to a $\mathrm{Hg}$-tetraselenolate complex $\left(\mathrm{Hg}(\mathrm{Sec})_{4}\right.$; $\mathrm{Sec}$, selenocysteine $)$ associated with selenoprotein $\mathrm{P}(\mathrm{SelP}){ }^{5} \mathrm{Hg}(\mathrm{Sec})_{4}$ bound to SelP, the latter containing at least ten Sec residues in vertebrates, ${ }^{6}$ is hypothesized to be the template for biomineralization of $\mathrm{HgSe}^{5}$ This hypothesis is strengthened by the observed co-existence of $\mathrm{Hg}(\mathrm{Sec})_{4}$ and $\mathrm{HgSe}$ in diverse tissues of seabirds (giant petrels, Macronectes spp.), ${ }^{7}$ mammals (long-finned pilot whales, Globicephala melas), ${ }^{8}$ and fish (blue marlin, Makaira sp.). ${ }^{9}$ The step-wise $\mathrm{MeHg} \rightarrow \mathrm{Hg}(\mathrm{Sec})_{4} \rightarrow \mathrm{HgSe}$ demethylation and biomineralization reactions appear to be universal in vertebrates. ${ }^{4,5,7-10}$ Notably, proportions of the three dominant chemical forms of $\mathrm{Hg}\left(\mathrm{MeHg}, \mathrm{Hg}(\mathrm{Sec})_{4}, \mathrm{HgSe}\right)$ vary considerably between tissues and organisms, the latter reflecting variable physiological efficiencies for $\mathrm{MeHg}$ detoxification for reasons yet known. These observations have important toxicological implications for the risk from $\mathrm{MeHg}$ to organisms.

Variations in the ratio of naturally occurring stable $\mathrm{Hg}$ isotopes provide complementary information on the internal transformations and exchange of $\mathrm{Hg}$ within organisms. Isotopic fractionation of $\mathrm{Hg}$ due to internal transformations has focused on the kinetic mass-dependent fractionation (MDF) of $\mathrm{Hg}$ for the $\mathrm{MeHg} \rightarrow \mathrm{Hg}(\mathrm{Sec})_{4}$ demethylation reaction. Waterbirds from diverse aquatic systems exhibited a constant fractionation of $\delta^{202} \mathrm{Hg}$ of $-2.2 \pm 0.1 \%$ for the $\mathrm{MeHg} \rightarrow \mathrm{Hg}(\mathrm{Sec})_{4}$ demethylation reaction, and a uniform $\mathrm{MeHg}$ isotopic composition between tissues, suggesting a rapid internal exchange of $\mathrm{MeHg}$ between tissues of the birds. ${ }^{11} \mathrm{MDF}$ due to $\mathrm{MeHg}$ demethylation accounts for the decrease in $\delta^{202} \mathrm{Hg}$ of tissues with decreasing fraction of $\mathrm{MeHg}(f(\mathrm{MeHg}))$, as observed in birds, ${ }^{11,12}$, fish ${ }^{13}$ and mammals, ${ }^{14-16}$ and parallel increase in $\delta^{202} \mathrm{Hg}$ of the residual $\mathrm{MeHg}$ in keratinized tissues. ${ }^{14,17,18}$

However, the $\delta^{202} \mathrm{Hg}$ values of tissues of higher trophic level organisms often cannot be explained by the simple mixing of two isotope endmembers (e.g., $\delta^{202} \mathrm{MeHg}$ and $\delta^{202} \mathrm{Hg}(\mathrm{Sec})_{4}$ ), as evidenced by significant variability in $\delta^{202} \mathrm{Hg}$ values in tissues with the same $f(\mathrm{MeHg})^{12-14}$ and the increase in $\delta^{202} \mathrm{Hg}$ values by $>1.0 \%$ in the liver of marine mammals as $f(\mathrm{MeHg})$ approaches zero. ${ }^{15,16,19} \mathrm{The} \delta^{202} \mathrm{Hg}$ of a tissue $\left(\delta^{202} \mathrm{Hg}_{t}\right)$ is the weighted sum of the $\delta^{202}\left(\mathrm{Sp}_{i}\right)_{t}$ values of the chemical species

$$
\delta^{202} \mathrm{Hg}_{t}=\sum f\left(\mathrm{Sp}_{i}\right)_{t} \times \delta^{202} \mathrm{Sp}_{i}
$$

and therefore other chemical forms of $\mathrm{Hg}$ (e.g., $\mathrm{HgSe}$ ) may explain behavior in $\delta^{202} \mathrm{Hg}$ in organisms. It was shown recently that the increase in $\delta^{202} \mathrm{Hg}$ in liver and kidneys of long-finned pilot whales at low $f(\mathrm{MeHg})$ fingerprints the transformation of $\mathrm{Hg}(\mathrm{Sec})_{4}$ to $\mathrm{HgSe}^{8}$

Aside from demethylation, other processes that fractionate $\mathrm{Hg}$ isotopes have not been documented within biota, including mass-independent fractionation (MIF; expressed as $\Delta^{199} \mathrm{Hg}, \Delta^{200} \mathrm{Hg}, \Delta^{201} \mathrm{Hg}$, $\Delta^{204} \mathrm{Hg}$ ) from kinetic processes or equilibrium isotope effects, the latter driven by both MDF and nuclear volume effect (NVE). ${ }^{20-22}$ A fundamental understanding of the internal processes controlling the isotopic fractionation of $\mathrm{Hg}$ in organisms is essential to fully utilize isotopic values for 
environmental applications, such as identifying the dietary origins of $\mathrm{MeHg},{ }^{11,} 23$ climate change effects, ${ }^{24}$ and response to changes in Hg sources. ${ }^{25,26}$

To address these science needs, the isotopic fractionation of $\mathrm{Hg}$ between the three prominent chemical forms of $\mathrm{Hg}\left(\mathrm{MeHg}, \mathrm{Hg}(\mathrm{Sec})_{4}, \mathrm{HgSe}\right)$ was quantified using diverse tissues of giant petrels. We measured the $\mathrm{Hg}$ isotopic composition of 23 tissues from eight giant petrels (P1-P8) analyzed previously for chemical speciation by HR-XANES and transmission electron microscopy (Figure 1). ${ }^{7}$ The giant petrels demethylate $\mathrm{MeHg}$ with extreme efficiency, with near-complete demethylation of $\mathrm{MeHg}$ in the muscle and varying degrees of $\mathrm{HgSe}$ biomineralization across diverse tissues (liver > kidneys $>$ muscle $\approx$ brain $).{ }^{7} \delta^{202} \mathrm{Hg}$ values of each chemical form of $\mathrm{Hg}\left(\delta^{202} \mathrm{MeHg}, \delta^{202} \mathrm{Hg}(\mathrm{Sec})_{4}\right.$, $\delta^{202} \mathrm{HgSe}$ ) were determined with high precision by the inversion of isotopic and spectroscopic data using linear algebra. The calculated $\delta^{202} \mathrm{MeHg}$ value was compared with values of $\delta^{202} \mathrm{MeHg}$ directly measured on a subset of tissues using an established method. ${ }^{27}$ The magnitude of isotopic fractionation quantified for the $\mathrm{MeHg} \rightarrow \mathrm{Hg}(\mathrm{Sec})_{4}$ reaction in the giant petrels contrasts with that quantified for waterbirds and mammals, indicating that fractionation patterns arise from different physiological efficiencies for demethylation. Further, mechanistic evidence is provided for the isotopic fractionation of $\mathrm{Hg}$ for the $\mathrm{Hg}(\mathrm{Sec})_{4} \rightarrow \mathrm{HgSe}$ biomineralization reaction. We discuss the implications of these findings for the toxicological understanding of $\mathrm{Hg}$ in organisms and the environmental application of stable $\mathrm{Hg}$ isotopes.

\section{MATERIALS AND METHODS}

Study animals. Giant petrels are large scavengers that feed primarily on carrion of marine mammals and other seabirds. They remain all year long within the Southern Ocean and in fringing subtropical waters. Being both top consumers and long-lived animals, giant petrels accumulate large amounts of mercury in their tissues. Eight dead specimens were opportunistically collected at the subantarctic Kerguelen Islands and in Adélie Land (Antarctica) and stored at $-20^{\circ} \mathrm{C}$ until dissection. All were adult males, but their exact age was unknown.

Mercury stable isotope measurement. All analyses for $\mathrm{Hg}$ stable isotopes were performed at the USGS Mercury Research Lab (Madison, WI). Tissues were digested in concentrated nitric acid $\left(\mathrm{HNO}_{3}\right)$ and heated at $80{ }^{\circ} \mathrm{C}$ for $8 \mathrm{~h}$. Sample digests were further oxidized using bromine monochloride $(\mathrm{BrCl})$ to $10 \%$ total volume and heated for an additional $2 \mathrm{~h}$ to ensure the degradation of any organic $\mathrm{Hg}$ species. Samples were diluted to $1-5 \% \mathrm{H}^{+}$content before isotope analysis. Concentration recoveries for digestions of certified reference material (DOLT-2, dogfish liver) were $105 \pm 3 \%(n=3)$.

Species-specific isotope measurements were performed on tissues that contained variable $f(\mathrm{MeHg})$ using a previously established distillation and anion-exchange resin method $(n=9) .{ }^{27}$ Briefly, samples were distilled to removed matrix interferences, and distillates were preserved to a final acid concentration of $0.5 \%$ hydrochloric acid $(\mathrm{HCl})$. After acidification, samples were passed through a pre-treated AG1-X4 resin column. ${ }^{27} \mathrm{MeHg}$ is neutrally charged under these conditions $(0.5 \% \mathrm{HCl})$ and therefore does not sorb to the AG1-X4 resin, whereas negatively charged inorganic species were sorbed to the AG1-X4 resin. If required, large volumes of eluent were further pre-concentrated using rapid gold amalgamation and collected into an oxidant trap. ${ }^{28} \mathrm{MeHg}$ isotope samples had acceptable recoveries, within $7 \%$ of previously measured $\mathrm{MeHg}$ concentrations, indicating no process-induced 
isotope fractionation. A certified reference material (DOLT-2) was also analyzed with samples and had acceptable recoveries (96 and 106\%; $n=2$ ) after distillation and resin preconcentration.

Total $\mathrm{Hg}$ and $\mathrm{MeHg}$ isotope samples were analyzed using a multicollector inductively coupled plasma mass spectrometer (MC-ICP-MS, Thermo Scientific). Analysis was conducted using standardsample bracketing with National Institute of Standards and Technology (NIST) 3133. Standards, samples, and reference materials were introduced to the MC-ICP-MS using stannous chloride reduction in a custom gas-liquid separator ${ }^{29}$ at a flow rate of $0.85 \mathrm{~mL} \mathrm{~min}^{-1}$. A thallium standard ( $\mathrm{Tl}$, $40.9 \mathrm{~g} / \mathrm{L}$ ) was simultaneously introduced to the gas-liquid separator for mass bias correction using a desolvating nebulizer (Apex, ESI). ${ }^{28}$ The MC-ICP-MS was tuned for optimal voltage and signal intensity for ${ }^{202} \mathrm{Hg}$ and ${ }^{205} \mathrm{Tl}$ prior to analysis.

Isotope values are expressed as $\delta^{\mathrm{XXX}} \mathrm{Hg}$ and $\Delta^{\mathrm{XXX}} \mathrm{Hg}$ in reference to NIST 3133. Isotope values of total $\mathrm{Hg}$ of tissues and the $\mathrm{MeHg}$ pool are denoted as $\delta^{202} \mathrm{Hg}_{\mathrm{f}}$ and $\delta^{202} \mathrm{MeHg}_{\mathrm{f}}$ for feathers, $\delta^{202} \mathrm{Hg}_{\mathrm{m}}$ and $\delta^{202} \mathrm{MeHg}_{\mathrm{m}}$ for muscle, $\delta^{202} \mathrm{Hg}_{\mathrm{k}}$ and $\delta^{202} \mathrm{MeHg}_{\mathrm{k}}$ for kidneys, $\delta^{202} \mathrm{Hg}_{1}$ and $\delta^{202} \mathrm{MeHg}_{1}$ for liver, and $\delta^{202} \mathrm{Hg}_{\mathrm{b}}$ and $\delta^{202} \mathrm{MeHg}_{\mathrm{b}}$ for brain, respectively. A secondary standard (NIST RM 8610, UM Almadén) was run every five samples to ensure accuracy and precision of measurements and isotope values agreed with certified values $\left(\delta^{202} \mathrm{Hg}=-0.55 \pm 0.06 \%, \Delta^{199} \mathrm{Hg}=-0.01 \pm 0.04 \%\right.$ o, $\Delta^{200} \mathrm{Hg}=0.01 \pm$ $0.04 \%, \Delta^{201} \mathrm{Hg}=-0.03 \pm 0.03 \%$ o, $\Delta^{204} \mathrm{Hg}=-0.01 \pm 0.06 \%$, 2SD; $\left.n=14\right)$. Certified reference material (DOLT-2) was comparable for total $\mathrm{Hg}$ and species-specific isotope measurements to literature values (Table S4). ${ }^{27}$ Furthermore, a comparison of total $\mathrm{Hg}$ and species-specific isotope measurements of three of the petrel feathers (P2, P4, and P5), which contained exclusively $\mathrm{MeHg}$, shows excellent agreement (Figure S7), with differences in values between total $\mathrm{Hg}$ and $\mathrm{MeHg} \leq 0.16 \%$ o, $\leq 0.03 \%$, $\leq 0.07 \%$, $\leq 0.03 \%$, and $\leq 0.05 \%$ or for $\delta^{202} \mathrm{Hg}, \Delta^{199} \mathrm{Hg}, \Delta^{201} \mathrm{Hg}, \Delta^{200} \mathrm{Hg}$, and $\Delta^{204} \mathrm{Hg}$, respectively. The aforementioned differences were an assessment of the precision of total $\mathrm{Hg}$ and species-specific isotope measurements. $\mathrm{Hg}$ stable isotope data generated during this study are available in the U.S. Geological Survey data repository. ${ }^{30}$

Data analysis. Species-specific $\delta^{202} \mathrm{Sp}_{i}$ values were calculated using the proportion of each species $\left(f\left(\mathrm{Sp}_{i}\right)_{t}\right)$ quantified by HR-XANES spectroscopy ${ }^{7}$ and the weighted average $\delta^{202} \mathrm{Hg}_{t}$ values as an inverse problem, which can be solved using linear algebra. ${ }^{31}$ Equation 1 can be represented as follows:

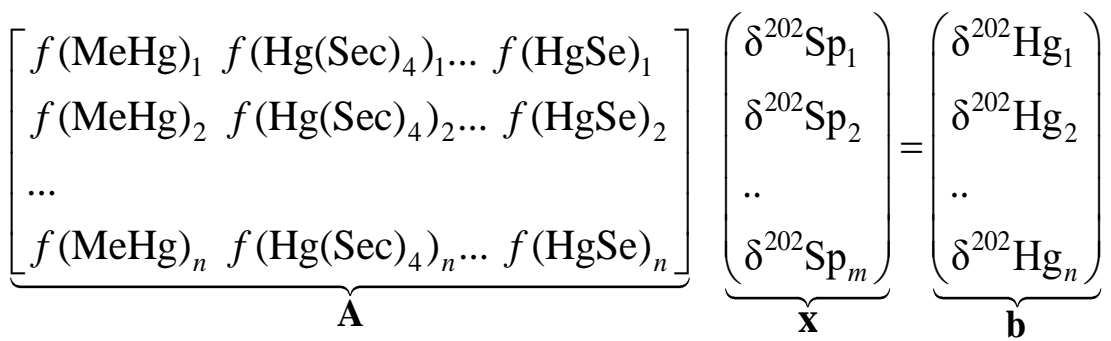

where $\mathbf{A}$ is a $n \times m$ matrix of the spectroscopic $f\left(\operatorname{Sp}_{i}\right)_{t}$ values, $n$ is the number of tissue samples (2223), and $m$ is the number of $\mathrm{Hg}$ species (3). $\mathbf{x}$ and $\mathbf{b}$ are two column vectors associated with the unknown $\delta^{202} \mathrm{Sp}_{i}$ values and the measured $\delta^{202} \mathrm{Hg}_{t}$ values, respectively. $\mathbf{x}$ can be obtained by minimizing the functional $\varphi(\mathbf{x})$, or residual, that quantifies the difference between the predicted $(\mathbf{A x})$ from the observed (b) data:

$\varphi(\mathbf{x})=\|\mathbf{A} \mathbf{x}-\mathbf{b}\|^{2}=(\mathbf{A} \mathbf{x}-\mathbf{b})^{\mathrm{T}} \mathbf{C}_{\mathrm{d}}^{-1}(\mathbf{A} \mathbf{x}-\mathbf{b})$ 
where $(\mathbf{A x}-\mathbf{b})^{\mathrm{T}}$ denotes the transpose of the vector $(\mathbf{A x}-\mathbf{b})$, and $\mathbf{C}_{\mathrm{d}}^{-1}$ is the inverse matrix of the squared standard deviations of the isotope measurements. Here, the total number of unknowns is $3\left(\delta^{202} \mathrm{MeHg}\right.$, $\delta^{202} \mathrm{Hg}(\mathrm{Sec})_{4}, \quad \delta^{202} \mathrm{HgSe}$ ) for 22-23 equations (i.e., tissues), therefore the inverse problem is overdetermined and the objective functional has a unique minimum. In our previous study on longfinned pilot whales ${ }^{8}$ the linear system had 92 unknowns for 89 equations. Therefore, the inverse problem was underdetermined and its resolution required the addition of a regularization term to Eq. (3).

As isotope measurements are independent, the input covariance $\mathbf{C}_{\mathrm{d}}$ matrix is diagonal and contains the experimental uncertainties on $\delta^{202} \mathrm{Hg}_{t}$. The unknown vector $\mathbf{x}$ is obtained at the minimum of $\varphi$, which is equivalent to zero in its first derivative:

$\partial_{\mathrm{x}} \varphi(\mathbf{x})=\mathbf{A}^{\mathrm{T}} \mathbf{C}_{\mathrm{d}}^{-1} \mathbf{A} \mathbf{x}-\mathbf{A}^{\mathrm{T}} \mathbf{C}_{\mathrm{d}}^{-1} \mathbf{b}=0$

giving

$$
\underbrace{\mathbf{A}^{\mathrm{T}} \mathbf{C}_{\mathrm{d}}^{-1} \mathbf{A}}_{\mathbf{B}} \mathbf{x}=\underbrace{\mathbf{A}^{\mathrm{T}} \mathbf{C}_{\mathrm{d}}^{-1} \mathbf{b}}_{\mathbf{y}}
$$

where $\mathbf{B}$ is a full ranked matrix and $\mathbf{y}$ a vector. Eq. 5 was solved with classical linear system resolution methods. In addition to providing $\mathbf{x}$, classical inverse problem theory provides an uncertainty assessment of the solution through the output covariance matrix $\mathbf{C}_{\mathrm{m}}$ :

$$
\mathbf{C}_{\mathrm{m}}=\left(\mathbf{A}^{\mathrm{T}} \mathbf{C}_{\mathrm{d}}^{-1} \mathbf{A}\right)^{-1}
$$

Its diagonal elements are the variances of the $\mathbf{x}$ values, which is the square of the standard deviations of the species-specific $\delta^{202} \mathrm{Sp}_{i}$ values, as evaluated from the uncertainties of the isotopic measurements $\left(\delta^{202} \mathrm{Hg}_{t}\right)$.

The linear inverse problem theory allows obtaining, in the least-squares sense, the optimal solution $\left(\mathbf{x}_{i}=\delta^{202} \mathrm{Sp}_{i}\right)$ to the set of equations $(\mathbf{A x})$ and its standard deviation. However, data are affected also by uncertainties on the species proportions $\left(f\left(\mathrm{Sp}_{i}\right)_{t}\right)$ obtained from the HR-XANES fits. The classical inverse problem treatment does not include uncertainties on the elements from the $\mathbf{A}$ matrix that contains the $f\left(\mathrm{Sp}_{i}\right)_{t}$ values. This uncertainty was assessed by introducing a statistical treatment to the numerical solutions obtained from the inverse analysis. Uncertainties on the finite $f\left(\mathrm{Sp}_{i}\right)_{t}$ values can be added to the $\mathbf{A}$ matrix by constructing the $\tilde{\mathbf{A}}$ matrix:

$$
\underbrace{(\mathbf{A}+\mathbf{C})}_{\tilde{\mathbf{A}}} \mathbf{x}=\mathbf{b}
$$

where $\mathbf{C}$ contains the variability on the $\mathbf{A}$ elements (i.e, precision on $\left.f\left(\mathrm{Sp}_{i}\right)_{t}\right)$. For example, the element $(i, j)$ of the matrix $\tilde{\mathbf{A}}$ is $\tilde{\mathbf{A}}(i, j)=\mathbf{A}(i, j) \pm \mathbf{C}(i, j)$. An ensemble of matrices $\tilde{\mathbf{A}}_{\mathrm{e}}$ can be constructed from a uniform random sampling of all $\tilde{\mathbf{A}}$ matrices spanned by the $\mathbf{C}(i, j)$ values. Each $\tilde{\mathbf{A}}_{\mathrm{e}}$ matrix is treated by the above-described inverse algorithm, yielding the new solution $\mathbf{x}_{\mathrm{e}}$. Considering a sufficiently large ensemble of $N \tilde{\mathbf{A}}_{\mathrm{e}}$ matrices, a mean solution $\overline{\mathbf{x}}$ can be computed from all solutions $\mathrm{X}=\left(\mathbf{x}_{1}, \mathbf{x}_{2}, \ldots\right.$, $\mathbf{x}_{\mathrm{n}}$ ). The covariance matrix of $\overline{\mathbf{x}}$ can be computed as $\tilde{\mathbf{C}}_{\mathrm{m}}=\frac{1}{N-1} \mathbf{M} \mathbf{M}^{\mathrm{T}}$, where the matrix $\mathbf{M}$ is built from the perturbation of the mean solution $\mathbf{M}=\left(\mathbf{x}_{1}-\overline{\mathbf{x}}, \mathbf{x}_{2}-\overline{\mathbf{x}}, \ldots, \mathbf{x}_{\mathrm{N}}-\overline{\mathbf{x}}\right)$. The diagonal elements of 
$\tilde{\mathbf{C}}_{\mathrm{m}}$ represent the variances and their square roots represent the standard deviations of $\overline{\mathbf{x}}$, which now include both the isotopic and spectroscopic uncertainties. $\overline{\mathbf{x}}$ and $\tilde{\mathbf{C}}_{\mathrm{m}}$ from the giant petrel data were converged after a few hundreds of random $\mathbf{C}(i, j)$ draws. Values reported herein correspond to $N=$ 1000. The Python code of the inversion algorithm is available in the Supporting Information and the GRICAD GitLab's site. ${ }^{32}$

\section{RESULTS}

The tissues and feathers of giant petrels exhibit large variability in $\delta^{202} \mathrm{Hg}_{t}$ values that follow a hierarchy across all individuals based on tissue type: feathers $\left(\delta^{202} \mathrm{Hg}_{\mathrm{f}}=2.74 \pm 0.16 \%, n=5\right.$, mean \pm standard deviation $)>$ brain $\left(\delta^{202} \mathrm{Hg}_{\mathrm{b}}=1.09 \pm 0.77 \%\right.$, $\left.n=3\right)>$ kidneys $\left(\delta^{202} \mathrm{Hg}_{\mathrm{k}}=0.01 \pm 0.25 \%, n=\right.$ $5)=\operatorname{liver}\left(\delta^{202} \mathrm{Hg}_{1}=0.04 \pm 0.11 \%, n=5\right)>$ muscle $\left(\delta^{202} \mathrm{Hg}_{\mathrm{m}}=-0.80 \pm 0.23 \%, n=5\right)$ (Figures 2 and 3 , Table S1). $\delta^{202} \mathrm{Hg}_{t}$ for liver tissues are within the range of literature data for seabirds $(-0.64 \%<$ $\delta^{202} \mathrm{Hg}_{1}<0.68 \%$ o), ${ }^{12}$ whereas $\delta^{202} \mathrm{Hg}$ for feathers are modestly higher than those measured previously for seabirds $\left(1.10 \%<\delta^{202} \mathrm{Hg}_{\mathrm{f}}<2.35 \%\right.$ ). ${ }^{12}{ }^{33}$ Notably, muscle tissues exhibit considerably lower $\delta^{202} \mathrm{Hg}_{t}$ values than liver tissues (on average $0.84 \%$ ), counter to observations to other birds and mammals, ${ }^{11,13-16,18}$ and were as much as approximately $-3.5 \%$ lower compared to feathers (Figure 2, Table S1). To the best of our knowledge, differences in $\delta^{202} \mathrm{Hg}$ of this magnitude are the largest reported between tissues in vertebrates. The relationship between $\delta^{202} \mathrm{Hg}_{t}$ and $f(\mathrm{MeHg}$ ) (Figure 3) shows a general trend of lower $\delta^{202} \mathrm{Hg}_{t}$ values in tissues with decreasing $f(\mathrm{MeHg})$ yet pronounced variability in $\delta^{202} \mathrm{Hg}_{t}$ values in tissues with $f(\mathrm{MeHg}) \leq 0.1$ (as great as $1.4 \%$ ). Under the premise that $\mathrm{Hg}$ in the petrel tissues reflects an integrated isotope signature of environmental sources, we interpret this variability to indicate that $\delta^{202} \mathrm{Hg}_{t}$ values cannot solely be explained by isotopic fractionation due to the demethylation of $\mathrm{MeHg}$ to a single inorganic $\mathrm{Hg}$ species (e.g., $\left.\mathrm{Hg}(\mathrm{Sec})_{4}\right)$. This observation is dissimilar to those in waterbirds with modest levels of demethylation, ${ }^{11}$ but similar to those in liver and kidneys of long-finned pilot whales with high levels of demethylation and formation of $\mathrm{HgSe} .^{15}$, 16

The analysis of tissues by HR-XANES spectroscopy quantified $\mathrm{Hg}$ as three primary species ( $\mathrm{MeHg}$, $\mathrm{Hg}(\mathrm{Sec})_{4}, \mathrm{HgSe}$ ) that vary in relative abundance (Figure 1, Table S2). ${ }^{7}$ The petrel feathers contain exclusively $\mathrm{MeHg}$, muscle and kidneys tissues contain mixtures of $\mathrm{Hg}(\mathrm{Sec})_{4}$ and $\mathrm{HgSe}$ with or without minor $\mathrm{MeHg}$, and the liver tissues contain almost exclusively $\mathrm{HgSe}(0.90 \leq f(\mathrm{HgSe}) \leq 1.00)$. Of the three brain tissues, $\mathrm{Hg}$ is present as a mixture of $\mathrm{MeHg}, \mathrm{Hg}(\mathrm{Sec})_{4}$, and $\mathrm{HgSe}$ with varying amounts of $\mathrm{MeHg}(0.13 \leq f(\mathrm{MeHg}) \leq 0.83)$. Taken together, the isotopic and spectroscopic results suggest that each $\mathrm{Hg}$ species has a unique $\delta^{202} \mathrm{Sp}_{i}$ value and the $\delta^{202} \mathrm{Hg}_{t}$ of tissues (Figure 2) are the weighted sum of $\delta^{202} \mathrm{MeHg}, \delta^{202} \mathrm{Hg}(\mathrm{Sec})_{4}$, and $\delta^{202} \mathrm{HgSe}$. This hypothesis was tested by solving for $\delta^{202} \mathrm{Sp}_{i}$ values the following 23 linear equations using an inversion algorithm ${ }^{8}$ :

$$
\delta^{202} \mathrm{Hg}_{t}=f(\mathrm{MeHg}) \times \delta^{202} \mathrm{MeHg}+f\left(\mathrm{Hg}(\mathrm{Sec})_{4}\right) \times \delta^{202} \mathrm{Hg}(\mathrm{Sec})_{4}+f(\mathrm{HgSe}) \times \delta^{202} \mathrm{HgSe}
$$

where $\delta^{202} \mathrm{Hg}_{t}$ is the measured isotopic value (Table S1) and the $\mathrm{Hg}$ species fractions $(f(\mathrm{MeHg})$, $f(\mathrm{Hg}(\mathrm{Sec}) 4), f(\mathrm{HgSe}))$ are the proportions obtained by HR-XANES for each tissue (Figure 1, Table S2). Three species-specific $\delta^{202} \mathrm{Hg}$ values proved sufficient to quantitatively describe the whole data set within experimental uncertainties (complete details on the inversion procedure are provided in the Methods section). Species-specific $\delta^{202} \mathrm{Hg}$ are $\delta^{202} \mathrm{MeHg}=2.68 \pm 0.04 \%$ o, $\delta^{202} \mathrm{Hg}(\mathrm{Sec})_{4}=-1.27 \pm 0.06$ 
$\%$, and $\delta^{202} \mathrm{HgSe}=0.19 \pm 0.02 \%$ (value \pm standard deviation). With twenty-three equations and only three unknowns, the mathematical system is overdetermined.

To verify this mathematical approach, $\delta^{202} \mathrm{Hg}_{t}$ values of tissues were recalculated (termed $\delta^{202} \mathrm{Hg}_{\text {calc }}$ ) using the established $\delta^{202} \mathrm{Sp}_{i}$ values and $f\left(\mathrm{Sp}_{i}\right)_{t}$ determined by HR-XANES (Eq. 8) (Table S2). Figure 4 shows excellent agreement between $\delta^{202} \mathrm{Hg}_{\text {calc }}$ and $\delta^{202} \mathrm{Hg}_{t}$ with a slope near unity (slope $=0.97$ ), indicating that the computational procedure provides robust isotopic solutions with uncertainties comparable to the precision of isotopic measurements (see Methods section) and is resistant to random and systematic errors in the independent spectroscopic and isotopic data sets. A single tissue was identified as an outlier (kidneys of individual P5 with $\delta^{202} \mathrm{Hg}_{\mathrm{k}}=0.26 \%$ and $\delta^{202} \mathrm{Hg}_{\text {calc }}$ $=-0.63 \%$ ) and was excluded from the data set to provide an improved estimate of $\delta^{202} \mathrm{Sp}_{i}$ values. After recalculation $\left(n=22\right.$, Eq. 8), the determined $\delta^{202} \mathrm{Sp}_{i}$ values were only marginally different $\left(\delta^{202} \mathrm{MeHg}=2.69 \pm 0.04 \%\right.$ o, $\delta^{202} \mathrm{Hg}(\mathrm{Sec})_{4}=-1.37 \pm 0.06 \%$, and $\delta^{202} \mathrm{HgSe}=0.18 \pm 0.02 \%$ o $)$, once again highlighting the robustness of the linear algebra approach. The recalculated $\delta^{202} \mathrm{Sp}_{i}$ values were further used in all formal analyses in this study.

To independently verify the $\delta^{202} \mathrm{Sp}_{i}$ values, MeHg was isolated from a subset of the tissues $(n=9$; Table S3), ${ }^{27}$ including at least one sample of each tissue type, for direct $\delta^{202} \mathrm{MeHg}$ measurement. Of the measured $\delta^{202} \mathrm{MeHg}$ values, five were in good agreement $(2.58-2.87 \%$ ) and within analytical precision (0.16\%, see Methods section) with the calculated $\delta^{202} \mathrm{MeHg}$ value $(2.69 \pm 0.04 \%$, whereas one was modestly higher (feathers for $\mathrm{P} 5, \delta^{202} \mathrm{MeHg}_{\mathrm{f}}=3.05 \%$ ) and three lower than the calculated $\delta^{202} \mathrm{MeHg}$ value (muscle and liver for $\mathrm{P} 3, \delta^{202} \mathrm{MeHg}_{\mathrm{m}}=2.07 \%$ and $\delta^{202} \mathrm{MeHg}_{1}=1.87 \%$; muscle for $\mathrm{P} 4, \delta^{202} \mathrm{MeHg}_{\mathrm{m}}=0.90 \%$ ). Notably, instances where measured $\delta^{202} \mathrm{MeHg}$ values deviated from the calculated $\delta^{202} \mathrm{MeHg}$ value were of muscle and liver tissues with low $\mathrm{MeHg}(f(\mathrm{MeHg})=0.07)$ or $\mathrm{MeHg}$ below the spectroscopic detection limit $(f(\mathrm{MeHg})<0.03)$. Thus, discrepancies between calculated and measured $\delta^{202} \mathrm{MeHg}$ values can, in part, be attributed to low $\mathrm{MeHg}$ levels of tissues being negligible in the computation of $\delta^{202} \mathrm{Sp}_{i}$ values. The feather with a modestly higher measured $\delta^{202} \mathrm{MeHg}$ value compared to that calculated (3.05 $\pm 0.03 \%$ versus $2.69 \pm 0.04 \%$, respectively) likely reflects subtle variability in $\delta^{202} \mathrm{Hg}$ typical of seabirds with diverse dietary sources and feeding ranges. ${ }^{11,12,19}$ Taken together, the aforementioned assessments highlight the precision and accuracy of calculated $\delta^{202} \mathrm{Sp}_{i}$ values by the inversion of isotopic and spectroscopic data.

The large variability in $\delta^{202} \mathrm{Hg}_{t}$ values in the petrel tissues $(\leq 3.5 \%$ ) is therefore due to the coexistence of $\mathrm{MeHg}$ and two inorganic species, $\mathrm{Hg}(\mathrm{Sec})_{4}$ and $\mathrm{HgSe}$, with contrasted $\delta^{202} \mathrm{Hg}$ values. Accordingly, the feathers with exclusively $\mathrm{MeHg}$ exhibit an average $\delta^{202} \mathrm{Hg}_{t}$ value weighted by measurement uncertainties of $2.71 \pm 0.06 \%$, consistent with $\delta^{202} \mathrm{MeHg}=2.69 \pm 0.04 \%$, and the liver tissues with nearly exclusively $\mathrm{HgSe}$ exhibit a weighted average $\delta^{202} \mathrm{Hg}_{t}$ values of $0.04 \pm 0.06 \%$ close to $\delta^{202} \mathrm{HgSe}=0.18 \pm 0.02 \%$ (Figure 1, Table S2). The $\delta^{202} \mathrm{Hg}_{t}$ values of muscle tissues are up to 1.2 \%o lower than those of kidney tissues due to the high proportion of $\mathrm{Hg}$ as isotopically distinct $\mathrm{Hg}(\mathrm{Sec})_{4}$ $\left(0.40 \leq f\left(\mathrm{Hg}(\mathrm{Sec})_{4}\right) \leq 0.72\right)$ with the same proportion of $\mathrm{MeHg}$. Further, the kidneys contain intermediate proportions of $\mathrm{Hg}(\mathrm{Sec})_{4}$ and $\mathrm{HgSe}$, yet a similar mean $\delta^{202} \mathrm{Hg}$ value than the liver $\left(\delta^{202} \mathrm{Hg}_{\mathrm{k}}\right.$ $=0.01 \pm 0.25 \%$ ). The reason is the presence of small proportions of $\mathrm{MeHg}$ in the kidneys $(0 \leq f(\mathrm{MeHg})$ $\leq 0.12$ ) that are not present in the liver. These observations underscore that the chemical speciation of $\mathrm{Hg}$ determines tissue-specific differences in $\delta^{202} \mathrm{Hg}$ values within and between petrels. 
The ratio of MIF anomalies $\left(\Delta^{199} \mathrm{Hg} / \Delta^{201} \mathrm{Hg}\right)$ of tissues shows a $\Delta^{199} \mathrm{Hg} / \Delta^{201} \mathrm{Hg}$ with a slope of 1.31 (Figure S1), which supports that photo-chemical processes prior to food web uptake are primarily responsible for $\Delta^{199} \mathrm{Hg}$ and $\Delta^{201} \mathrm{Hg}$ values within petrel tissues. Surprisingly, a careful analysis of the data identifies that $\Delta^{199} \mathrm{Hg}$ and $\Delta^{201} \mathrm{Hg}$ values in liver and kidney tissues were significantly lower than values of the $\mathrm{MeHg}$ pool as determined by feather values (predominantly $\mathrm{MeHg}$ ) and direct $\mathrm{MeHg}$ isotope measurements from muscle, liver, or kidneys (t-test, $p$-value $<0.001, n=20$; Figure S2). There was an observed hierarchy in $\Delta^{199} \mathrm{Hg}$ and $\Delta^{201} \mathrm{Hg}$ values across the five petrels, which we interpret to reflect subtle differences in the isotopic signature of $\mathrm{Hg}$ from environmental sources. Despite this subtle variability, liver and kidney tissue $\Delta^{199} \mathrm{Hg}$ and $\Delta^{201} \mathrm{Hg}$ values were $1.43 \pm 0.08$ and $1.27 \pm 0.06$ $\%$ (average \pm standard deviation, $n=10$ ) compared to $1.68 \pm 0.06$ and $1.45 \pm 0.06 \%$ for $\mathrm{MeHg}(n=8)$, respectively. These differences greatly exceed the analytical precision of $\leq 0.03$ and $\leq 0.07 \%$ for $\Delta^{199} \mathrm{Hg}$ and $\Delta^{201} \mathrm{Hg}$, respectively (Figure S7, Table S5). Conversely, the differences in $\Delta^{200} \mathrm{Hg}$ and $\Delta^{204} \mathrm{Hg}$ values between the liver and kidney tissues $(-0.02 \pm 0.02 \%$ and $0.05 \pm 0.04 \%$, respectively) and $\mathrm{MeHg}$ pool $(0.00 \pm 0.02 \%$ and $0.01 \pm 0.04 \%$, respectively) were negligible and within the analytical precision $\left(\leq 0.03\right.$ and $\leq 0.05 \%$ for $\Delta^{200} \mathrm{Hg}$ and $\Delta^{204} \mathrm{Hg}$ measurements, respectively; Figure S7).

Previous HR-XANES and species-specific isotope measurements of birds from diverse aquatic systems demonstrate that the $\mathrm{MeHg} \rightarrow \mathrm{Hg}(\mathrm{Sec})_{4}$ demethylation reaction does not induce MIF. ${ }^{11}$ Therefore, we evaluated if the $\mathrm{Hg}(\mathrm{Sec})_{4} \rightarrow \mathrm{HgSe}$ biomineralization reaction could be responsible for the observed MIF. Complete details of this analysis are provided in the Supporting Information and summarized in Table S4. For each petrel (P1-P5), "initial" $\Delta{ }^{199} \mathrm{Hg}$ and $\Delta^{201} \mathrm{Hg}$ values were assigned using measurements of $\mathrm{MeHg}$, either of feathers or $\mathrm{MeHg}$ extracts of tissues, as no petrel tissues contained exclusively $\mathrm{Hg}(\mathrm{Sec})_{4}$ (Figure 1, Table S2). Next, differences in $\Delta^{199} \mathrm{Hg}$ and $\Delta^{201} \mathrm{Hg}$ were calculated for each individual between the "initial" $\mathrm{MeHg}$ pool and $\mathrm{HgSe}$, the latter determined using liver tissues that contain nearly exclusively $\mathrm{HgSe}$. Differences in $\Delta^{199} \mathrm{Hg}$ and $\Delta^{201} \mathrm{Hg}$ between $\mathrm{MeHg}$ and $\mathrm{HgSe}$ range from -0.10 to $-0.32 \%$ and from -0.06 to $-0.21 \%$ in the five individuals, respectively. The ratio of the difference in $\Delta^{199} \mathrm{Hg}$ to the difference in $\Delta^{201} \mathrm{Hg}$ (Diff. $\Delta^{199} \mathrm{Hg} / \mathrm{Diff}$. $\Delta^{201} \mathrm{Hg}$ ) between $\mathrm{MeHg}$ and $\mathrm{HgSe}$ was $1.6 \pm 0.3$ (average \pm standard deviation, $n=5$ ) and is compared graphically in Figure $\mathrm{S} 4$ to $\Delta^{199} \mathrm{Hg} / \Delta^{201} \mathrm{Hg}$ ratios quantified previously for dark nuclear volume effect (NVE, $\left.1.54 \pm 0.22 ;{ }^{21} 1.59 \pm 0.05\right)^{22}$ and photochemical processes (1.0 to 1.35$) .{ }^{34}$ Consistency in the fractionation of $\Delta^{199} \mathrm{Hg}$ relative to $\Delta^{201} \mathrm{Hg}$ between $\mathrm{MeHg}$ and $\mathrm{HgSe}$ in the petrel and dark NVEs supports that equilibrium isotope effects underlie the isotopic fractionation for the $\mathrm{Hg}(\mathrm{Sec})_{4} \rightarrow \mathrm{HgSe}$ biomineralization reaction.

\section{DISCUSSION}

We demonstrate that the $\delta^{202} \mathrm{Hg}$ values of diverse tissues of giant petrels can be described with a high degree of confidence as a weighted average of three species-specific $\delta^{202} \mathrm{Sp}_{i}$ values corresponding to those of $\mathrm{MeHg}, \mathrm{Hg}(\mathrm{Sec})_{4}$, and $\mathrm{HgSe}$ identified by HR-XANES. ${ }^{7}$ The quantification of $\delta^{202} \mathrm{Sp}_{i}$ values is accomplished using the novel inversion of isotopic and spectroscopic data. ${ }^{8}$ Observed differences in species-specific $\delta^{202} \mathrm{Sp}_{i}$ values are interpreted to reflect the isotopic fractionation of $\mathrm{Hg}$ of two internal transformations, the $\mathrm{MeHg} \rightarrow \mathrm{Hg}(\mathrm{Sec})_{4}$ demethylation reaction $\left(-4.1 \pm 0.1 \%\right.$ ) and $\mathrm{Hg}(\mathrm{Sec})_{4} \rightarrow \mathrm{HgSe}$ biomineralization reaction $(+1.6 \pm 0.1 \%$ ). The latter transformation that induced fractionation of 
$\delta^{202} \mathrm{Hg}$ was accompanied by modest decreases in $\Delta^{199} \mathrm{Hg}$ and $\Delta^{201} \mathrm{Hg}$ values in the liver and kidneys tissues (magnitude of changes of $\leq 0.3 \%$ and $\leq 0.2 \%$, respectively). The species-specific $\delta^{202} \mathrm{Sp}_{i}$ values of $\mathrm{MeHg}, \mathrm{Hg}(\mathrm{Sec})_{4}$, and $\mathrm{HgSe}$ were consistent across diverse tissues of all eight petrels, indicating that total $\delta^{202} \mathrm{Hg}$ tissue values arise from varying mixtures of $\mathrm{Hg}$ species and that both $\mathrm{MeHg}$ and inorganic $\mathrm{Hg}$ redistribute internally. ${ }^{15}$ Therefore, the large negative fractionation of $\delta^{202} \mathrm{Hg}$ due to $\mathrm{MeHg}$ to $\mathrm{Hg}(\mathrm{Sec})_{4}$ demethylation and subsequent positive fractionation in $\delta^{202} \mathrm{Hg}$ values due to $\mathrm{Hg}(\mathrm{Sec})_{4} \rightarrow$ HgSe biomineralization can explain the variability of $\delta^{202} \mathrm{Hg}$ observed in and across biological tissues of vertebrates, ${ }^{14,16,19,24}$ highlighting the importance of chemical speciation of $\mathrm{Hg}$ on stable $\mathrm{Hg}$ isotope values. Below we discuss the results that support the aforementioned interpretations and detail the implications of these findings for the toxicological understanding of $\mathrm{Hg}$ in high trophic level organisms and environmental application of stable $\mathrm{Hg}$ isotopes.

Isotope Fractionation Due to Internal Demethylation and Biomineralization Reactions. The lower $\delta^{202} \mathrm{Hg}$ in $\mathrm{Hg}(\mathrm{Sec})_{4}$ is attributed to MDF from a chemical kinetic isotope effect of $\mathrm{Hg}^{35}$ during enzymatic demethylation of $\mathrm{MeHg}^{36}$ and complexation to $\mathrm{SelP}^{5}$, a process documented in other waterbirds ${ }^{11}$ and long-finned pilot whales ${ }^{8}$. The underlying reason for the greater $\delta^{202} \mathrm{Hg}$ in $\mathrm{HgSe}$ is less clear, but several lines of evidence support that changes in the $\mathrm{Hg}$ bonding environment are responsible for it. First, the $\mathrm{Hg}(\mathrm{Sec})_{4} \rightarrow \mathrm{HgSe}$ transformation is not a one-step reaction but proceeds via a multi-step reaction mechanism $\mathrm{Hg}(\mathrm{Sec})_{4} \rightarrow \mathrm{Hg}_{x}(\mathrm{Se}, \mathrm{Sec})_{y} \rightarrow \mathrm{HgSe}^{5,}$, 9 The multinuclear intermediate $\mathrm{Hg}_{x}(\mathrm{Se}, \mathrm{Sec})_{y}$ species, which is spectroscopically and isotopically indistinguishable from $\mathrm{Hg}(\mathrm{Sec})_{4}$ when disordered ${ }^{11}$ undergoes biomineralization to nanocrystalline $\mathrm{HgSe}^{7}$ as the ratio of $x$ to $y$ increases from 1:4 to 1:1 and Sec (selenocysteine) residues are replaced by inorganic Se ligands. Importantly, the isotopic fractionation of $\mathrm{Hg}$ attributed to the $\mathrm{Hg}(\mathrm{Sec})_{4} \rightarrow \mathrm{HgSe}$ transformation is observed in the petrels concurrent with HR-XANES and electron microscopy evidence for an increase in crystallinity of disordered $\mathrm{Hg}_{x}(\mathrm{Se}, \mathrm{Sec})_{y}$ to $\mathrm{HgSe}^{7}$

Second, the observed fractionation of $\delta^{202} \mathrm{Hg}$ between $\mathrm{Hg}(\mathrm{Sec})_{4}$ and $\mathrm{HgSe}$ is accompanied by significant decreases in $\Delta^{199} \mathrm{Hg}$ and $\Delta^{201} \mathrm{Hg}$ (Figure S2). The differences in $\Delta^{199} \mathrm{Hg}$ relative to $\Delta^{201} \mathrm{Hg}$ between $\mathrm{MeHg}$ and $\mathrm{HgSe}$ in the petrels (1.6 \pm 0.3$)$, which indicate the isotope fractionation process, are consistent with the measured and theoretical ratios for NVE (mean of $1.54-1.59$ and 1.65, respectively). ${ }^{21,}{ }^{22}$ Notably, the magnitude of isotope differences attributed to $\mathrm{Hg}(\mathrm{Sec})_{4} \rightarrow \mathrm{HgSe}$ biomineralization $\left(\delta^{202} \mathrm{Hg}=1.6 \% ; \Delta^{199} \mathrm{Hg} \leq 0.3 \% ; \Delta^{201} \mathrm{Hg} \leq 0.2 \%\right.$ ) in giant petrels are greater than those observed previously in laboratory experiments between aqueous $\mathrm{Hg}$ (II) complexes and a bidentate thiol complex ( $\leq 0.6 \%$ o, $\leq 0.1 \%$, and $\leq 0.05 \%$, respectively), ${ }^{21}$ perhaps due to the multidentate nature of the $\mathrm{Hg}$-Se complexes and biomineralization of disordered $\mathrm{Hg}_{x}(\mathrm{Se}, \mathrm{Sec})_{y}$ to compact, crystalline $\mathrm{HgSe}$. Although other processes could explain these observations, the directionality and relative magnitude of isotopic fractionation in the tissues are remarkably similar to laboratory experiments and theoretical calculations of equilibrium isotope effects from MDF and $\mathrm{NVE}^{21,22}$ and inconsistent with other phenomena (e.g., MIF by kinetic magnetic isotope effects). ${ }^{34}$ Thus, we assert that equilibrium isotope effects of MDF and NVE are likely responsible for the isotopic fractionation between $\mathrm{Hg}(\mathrm{Sec})_{4}$ and $\mathrm{HgSe}$. This is the first study in natura documenting evidence for NVE of $\mathrm{Hg}$ due to dark biotic transformation.

Isotopic and spectroscopic measurements of other seabirds, fish, and mammals support our interpretations. In long-finned pilot whales (G. melas), the analysis of $\mathrm{HgSe}$ nanoparticles from the 
liver show $\delta^{202} \mathrm{Hg}$ values increase from $-0.85 \pm 0.06 \%$ at 2.5 years of age to $-0.09 \pm 0.06 \%$ at 29 years of age as the particles increase in size, in agreement with the isotopic evolution of $\mathrm{Hg}$ with a progressive increase of the ratio of $x$ to $y$ of $\mathrm{Hg}_{x}(\mathrm{Se}, \mathrm{Sec})_{y}$ towards $\mathrm{HgSe}$. Further, the magnitude of isotopic fractionation of $\delta^{202} \mathrm{Hg}$ between $\mathrm{Hg}(\mathrm{Sec})_{4}$ and $\mathrm{HgSe}$ is comparable in the long-finned pilot whales $(+1.4 \%)^{8}$ and giant petrels $\left(+1.6 \%\right.$ ). In regards to MIF anomalies, $\Delta^{199} \mathrm{Hg}$ and $\Delta^{201} \mathrm{Hg}$ values of long-finned pilot whales of $\mathrm{Li}$ et al. ${ }^{16}$ are significantly lower $(\leq \sim 0.25 \%)$ in the liver compared to the muscle of adult whales (Figure S5), which was not identified by the authors of the study, and consistent with $\mathrm{HgSe}$ biomineralization primarily in the adult whale liver. ${ }^{8}$ A separate study of beluga whale liver tissues (Delphinapterus leucas) shows increases in $\delta^{202} \mathrm{Hg}$ concomitant with decreases in $\Delta^{199} \mathrm{Hg}$ in older individuals not explained by ecological factors (e.g., no differences in $\delta^{15} \mathrm{~N}$ and $\delta^{13} \mathrm{C}$ which are indicative of shifts in foraging behavior). Beyond whales, further indirect evidence for the occurrence of $\mathrm{Hg}(\mathrm{Sec})_{4}$ is provided in the literature by the deviation from a linear correlation between $\delta^{202} \mathrm{Hg}$ and $f(\mathrm{MeHg})$ in marine fish (Brosme brosme), ${ }^{13}$ other seabirds (Pachyptila desolata, Procellaria aequinoctialis), ${ }^{12}$ and seals (Phoca sibirica). ${ }^{14,19} \delta^{202} \mathrm{Hg}$ differed by as much as $1.2 \%$ between liver and muscle tissues of giant petrels in this study and $1.6 \%$ in two other giant petrels with identical low $f\left(\mathrm{MeHg}\right.$ ) (Figure S6), ${ }^{12}$ which are supporting evidence for a mixture of isotopically distinct $\mathrm{HgSe}$ and $\mathrm{Hg}(\mathrm{Sec})_{4}$. Thus, the isotopic fractionation due to $\mathrm{Hg}(\mathrm{Sec})_{4} \rightarrow \mathrm{HgSe}$ biomineralization appears to occur in diverse vertebrates.

The magnitude of measured isotopic fractionation of $\delta^{202} \mathrm{Hg}$ for the $\mathrm{MeHg} \rightarrow \mathrm{Hg}(\mathrm{Sec})_{4}$ demethylation reaction is significantly greater in giant petrels $(-4.1 \pm 0.1 \%$ o $)$ than other waterbirds $(-2.2 \pm 0.1 \% \text { o })^{11}$ and long-finned pilot whales $(-2.6 \pm 0.1 \% \text { o })^{8}$ This observation is likely explained by physiological differences between organisms in the rate of demethylation relative to new dietary $\mathrm{MeHg}$ intake and $\mathrm{MeHg}$ depuration, rather than mechanistic differences in the demethylation reaction. The giant petrels demethylate $\mathrm{MeHg}$ with extreme efficiency, as indicated by (1) predominantly inorganic $\mathrm{Hg}$ in the muscle, kidneys, and liver, and (2) a vast isotopic difference $(-4.1 \%$ ) between reactant (i.e., $\mathrm{MeHg}$ ) and product (i.e., $\left.\mathrm{Hg}(\mathrm{Sec})_{4}\right)$. In contrast, waterbirds from diverse aquatic environments with modest levels of demethylation, including a south polar skua (Stercorarius maccormicki) from the same geographic area as the giant petrels, exhibited an isotopic difference between $\mathrm{MeHg}$ and $\mathrm{Hg}(\mathrm{Sec})_{4}$ of $-2.2 \%$. ${ }^{11}$ We propose that organisms that exhibit faster $\mathrm{MeHg} \rightarrow$ $\mathrm{Hg}(\mathrm{Sec})_{4}$ demethylation relative to dietary $\mathrm{MeHg}$ replenishment and $\mathrm{MeHg}$ depuration via keratinized tissues $^{2}$ will behave increasingly like a closed isotope system rather than an open isotope system with infinite reactant reservoirs (i.e., $\mathrm{MeHg}$ ), resulting in a residual $\mathrm{MeHg}$ pool with a greater positive $\delta^{202} \mathrm{Hg}$ offset and expansion in the measured isotopic fractionation between $\mathrm{MeHg}$ and $\mathrm{Hg}(\mathrm{Sec})_{4}$. This assessment is supported by $\delta^{202} \mathrm{Hg}$ values of feathers in this study exceeding all previous observations of Antarctic seabirds ${ }^{12,33}$ and consistent with observations in Arctic seabirds. ${ }^{19}$ Physiological controls on demethylation efficiency in birds and other animals are unknown but may depend on the availability of Se and rate of transcription of the SelP gene..$^{37,38}$ 
Internal Redistribution of MeHg and Inorganic Hg. The speciation and isotopic results provide a new understanding of the metabolic routing of $\mathrm{Hg}$ between tissues (Figure 5). The relative invariance of $\delta^{202} \mathrm{MeHg}$ between tissues and across individual petrels can be explained by (1) the continuous supply of new dietary $\mathrm{MeHg}$ with similar isotopic composition, and its cellular uptake from, and efflux to, the blood, ${ }^{39}$ and (2) the highly labile nature of the $\mathrm{Hg}$-SR bond, ${ }^{40}$ that results in rapid internal cycling of $\mathrm{MeHg}$ with a greater $\delta^{202} \mathrm{Hg}$ value(i.e., kinetic isotope effect).

The observed invariance of $\delta^{202} \mathrm{Hg}(\mathrm{Sec})_{4}$ and $\delta^{202} \mathrm{HgSe}$ can be explained by (1) the formation of $\mathrm{Hg}(\mathrm{Sec})_{4}$ from $\mathrm{MeHg}$ of uniform isotopic composition and (2) the internal redistribution of inorganic $\mathrm{Hg}$, perhaps as $\mathrm{Hg}(\mathrm{Sec})_{4}$. Mechanistic studies in nature linking tissue-specific transformations of $\mathrm{Hg}$ and internal redistribution in the circulatory system are lacking and needed. Notwithstanding, HgSe granules should be immobile because they are aggregated. ${ }^{7}$ SelP is expressed and secreted in plasma primarily by the liver and secondarily by extrahepatic tissues (e.g., heart and brain) ${ }^{37,38,41-45}$ and is taken up into cells through the apolipoprotein E Receptor-2 (ApoER2) to supply Se for selenoprotein synthesis. ${ }^{46-49}$ It is likely that $\mathrm{MeHg}$ is demethylated to $\mathrm{Hg}(\mathrm{Sec})_{4}$ by $\mathrm{SelP}$ and $\mathrm{Hg}(\mathrm{Sec})_{4}$ bound to SelP is redistributed to other tissues, including muscle, ${ }^{12-17,19}$ via the circulatory system. Under this scheme, the biomineralization of $\mathrm{HgSe}$ within hepatic and extrahepatic tissues occurs from $\mathrm{Hg}(\mathrm{Sec})_{4}$ of uniform isotopic composition, and $\mathrm{Hg}(\mathrm{Sec})_{4}$ forms from isotopically uniform $\mathrm{MeHg}$. Previous observation of $\mathrm{Hg}$-bound SelP in the plasma of Inuits supports this interpretation, ${ }^{50}$ as does isotopic differences between the blood of long-finned pilot whales compared to tissue MeHg values. ${ }^{15}$ Further research is needed to establish linkages between $\mathrm{Hg}$ transformations and Se homeostasis, which, along with evidence for the highly labile nature of the $\mathrm{Hg}$-ligand complexes in biological systems, ${ }^{40}$ will fuel the advancement of toxicokinetic models on $\mathrm{Hg}$.

Implications for Environmental Application of Hg Stable Isotopes. Stable $\mathrm{Hg}$ isotopes are frequently used tools in the examination of $\mathrm{Hg}$ bioaccumulation in high trophic level organisms, often focusing on pressing environmental questions in $\mathrm{Hg}$ science, and will undoubtedly aid in improving our understanding of $\mathrm{Hg}$ cycling and monitoring the effectiveness of global $\mathrm{Hg}$ mitigation strategies (i.e. Minamata Convention on Mercury). ${ }^{25,} 26$ Our findings demonstrate that stable $\mathrm{Hg}$ isotope values in top predators are highly dependent on the chemical speciation of $\mathrm{Hg}$ and can reflect both kinetic and equilibrium isotope effects during internal transformations, which need to be considered if stable $\mathrm{Hg}$ isotopes are used for source apportionment. The accurate interpretation of stable $\mathrm{Hg}$ isotopes in birds and mammals necessitates a quantitative understanding of the chemical speciation of $\mathrm{Hg}$ across all tissue types, as internal demethylation and biomineralization transformations can exert dramatic, bidirectional influence on $\delta^{202} \mathrm{Hg}$ values of hepatic and non-hepatic tissues (e.g., muscle) and more subtle shifts in $\Delta^{199} \mathrm{Hg}$ in primarily liver tissues. Across organisms, differences in the physiological efficiency of the $\mathrm{MeHg} \rightarrow \mathrm{Hg}(\mathrm{Sec})_{4}$ demethylation reaction will influence the $\delta^{202} \mathrm{Hg}$ value of the residual $\mathrm{MeHg}$ pool across all tissues and measured isotopic fractionation for the $\mathrm{MeHg} \rightarrow \mathrm{Hg}(\mathrm{Sec})_{4}$ reaction. This likely explains the observed range in isotopic $\delta^{202} \mathrm{Hg}$ offset between dietary $\mathrm{MeHg}$ and $\mathrm{MeHg}$ in wildlife and humans (from +0.3 to $+2.0 \%$ ) from previous work. ${ }^{17,18,51,52}$ The findings further provoke a revisitation of the notion that internal transformations of $\mathrm{Hg}$ cannot induce MIF, as evidenced in modest $\mathrm{MIF}$ from $\mathrm{Hg}(\mathrm{Sec})_{4} \rightarrow \mathrm{HgSe}$ biomineralization in seabirds and whales.

Our results demonstrate that the speciation of $\mathrm{Hg}$ should be quantified, and not assumed, irrespective of tissue type, ${ }^{5,7,9,11}$ particularly in organisms that have different extents of internal 
demethylation. When the tissue-specific fractions of $\mathrm{MeHg}, \mathrm{Hg}(\mathrm{Sec})_{4}$, and $\mathrm{HgSe}$ are known $\left(f\left(\mathrm{Sp}_{i}\right)_{t}\right)$, as in this study, their isotopic $\delta^{202} \mathrm{Hg}$ values $\left(\delta^{202} \mathrm{Sp}_{i}\right)$ resulting from demethylation and biomineralization reactions can be obtained mathematically by linear algebra (see SI). In this case, the linear system is well-posed and the $\delta^{202} \mathrm{Sp}_{i}$ solution is unique. If only $f(\mathrm{MeHg})_{\mathrm{t}}$ is known, typically from chemical analysis, the linear system is modestly ill-posed and unique meaningful $\delta^{202} \mathrm{Sp}_{i}$ values still can be obtained by regularization techniques, as demonstrated for long-finned pilot whales. ${ }^{8,53}$

Often the goal of $\mathrm{Hg}$ stable isotope applications is to connect $\mathrm{Hg}$ within the food web back to specific sources or processes, which becomes demonstrably more difficult when multiple $\mathrm{Hg}$ chemical species are present and contribute to the total $\mathrm{Hg}$ isotope pool. Our observations have important implications for $\mathrm{Hg}$ isotope source assessments in marine animals, especially baseline studies targeting climate change and the effectiveness of the Minamata Convention on Mercury, and suggest that interpretations can be skewed if $\mathrm{Hg}$ speciation is not considered. With these considerations in mind, the advancements presented here and elsewhere on new analytical and mathematical tools ${ }^{5,7}, 11$ in $\mathrm{Hg}$ science will propel an improved mechanistic understanding on $\mathrm{Hg}$ transformation and toxicology in biota and facilitate applications of isotopic and spectroscopic approaches at the organism and ecosystem level.

\section{REFERENCES}

(1) Eagles-Smith, C. A.; Silbergeld, E. K.; Basu, N.; Bustamante, P.; Diaz-Barriga, F.; Hopkins, W. A.; Kidd, K. A.; Nyland, J. F. Modulators of mercury risk to wildlife and humans in the context of rapid global change. Ambio 2018, 47, 170-197.

(2) Chételat, J.; Ackerman, J. T.; Eagles-Smith, C. A.; Hebert, C. E. Methylmercury exposure in wildlife: A review of the ecological and physiological processes affecting contaminant concentrations and their interpretation. Sci. Tot. Environ. 2020, 711, n ${ }^{\circ} 135117$.

(3) Korbas, M.; O'Donoghue, J. L.; Watson, G. E.; Pickering, I. J.; Singh, S. P.; Myers, G. J.; Clarkson, T. W.; George, G. N. The chemical nature of mercury in human brain following poisoning or environmental exposure. ACS Chem. Neurosci. 2010, 1, 810-818.

(4) Gajdosechova, Z.; Lawan, M. M.; Urgast, D. S.; Raab, A.; Scheckel, K. G.; Lombi, E.; Kopittke, P. M.; Loeschner, K.; Larsen, E. H.; Woods, G.; Brownlow, A.; Read, F. L.; Feldmann, J.; Krupp, E. M. In vivo formation of natural $\mathrm{HgSe}$ nanoparticles in the liver and brain of pilot whales. Sci. Rep. 2016, 6, 34361 .

(5) Manceau, A.; Bourdineaud, J. P.; Oliveira, R. B.; Sarrazin, S. L. F.; Krabbenhoft, D. P.; EaglesSmith, C. A.; Ackerman, J. T.; Stewart, A. R.; Ward-Deitrich, C.; Busto, M. E. D.; Goenaga-Infante, H.; Wack, A.; Retegan, M.; Detlefs, B.; Glatzel, P.; Bustamante, P.; Nagy, K. L.; Poulin, B. A. Demethylation of methylmercury in bird, fish, and earthworm. Environ. Sci. Technol. 2021, 55, $1527-$ 1534.

(6) Labunskyy, V. M.; Hatfield, D. L.; Gladyshev, V. N. Selenoproteins: Molecular pathways and physiological roles. Physiol. Rev. 2014, 94, 739-777.

(7) Manceau, A.; Gaillot, A. C.; Glatzel, P.; Cherel, Y.; Bustamante, P. In vivo formation of HgSe nanoparticles and $\mathrm{Hg}$-tetraselenolate complex from methylmercury in seabird - Implications for the Hg-Se antagonism. Environ. Sci. Technol. 2021, 55, 1515-1526. 
(8) Manceau, A.; Brossier, R.; Poulin, B. A. Chemical forms of mercury in pilot whales determined from species-averaged mercury isotope signatures. ACS Earth Space Chem. 2021, 5, 1591-1599.

(9) Manceau, A.; Azemard, S.; Hédouin, L.; Vassileva, E.; Lecchini, D.; Fauvelot, C.; Swarzenski, P. W.; Glatzel, P.; Bustamante, P.; Metian, M. The chemical forms of mercury in blue marlin billfish: Implications for human exposure. Environ. Sci.. Technol. Lett. 2021, 8, 405-411.

(10) Arai, T.; Ikemoto, T.; Hokura, A.; Terada, Y.; Kunito, T.; Tanabe, S.; Nakai, I. Chemical forms of mercury and cadmium accumulated in marine mammals and seabirds as determined by XAFS analysis. Environ. Sci. Technol. 2004, 38, 6468-6474.

(11) Poulin, B. A.; Janssen, S. E.; Rosera, T. J.; Krabbenhoft, D. P.; Eagles-Smith, C. A.; Ackerman, J. T.; Stewart, A. R.; Kim, E.; Baumann, Z.; Kim, J. H.; Manceau, A. Isotope fractionation from in vivo methylmercury detoxification in waterbirds. ACS Earth Space Chem. 2021, 990-997.

(12) Renedo, M.; Pedrero, Z.; Amouroux, D.; Cherel, Y.; Bustamante, P. Mercury isotopes of key tissues document mercury metabolic processes in seabirds. Chemosphere 2021, 263, $\mathrm{n}^{\circ} 127777$.

(13) Rua-Ibarz, A.; Bolea-Fernandez, E.; Maage, A.; Frantzen, S.; Sanden, M.; Vanhaecke, F. Tracing mercury pollution along the Norwegian coast via elemental, speciation, and isotopic analysis of liver and muscle tissue of deep-water marine fish (Brosme brosme). Environ. Sci. Technol. 2019, 53, 17761785.

(14) Perrot, V.; Masbou, J.; Pastukhov, M. V.; Epov, V. N.; Point, D.; Berail, S.; Becker, P. R.; Sonke, J. E.; Amouroux, D. Natural Hg isotopic composition of different $\mathrm{Hg}$ compounds in mammal tissues as a proxy for in vivo breakdown of toxic methylmercury. Metallomics 2016, 8, 170-178.

(15) Bolea-Fernandez, E.; Rua-Ibarz, A.; Krupp, E. M.; Feldmann, J.; Kvanhaecke, F. High-precision isotopic analysis sheds new light on mercury metabolism in long-finned pilot whales (Globicephala melas). Sci. Rep. 2019, 9, n 7262.

(16) Li, M. L.; Juang, C. A.; Ewald, J. D.; Yin, R. S.; Mikkelsen, B.; Krabbenhoft, D. P.; Balcom, P. H.; Dassuncao, C.; Sunderland, E. M. Selenium and stable mercury isotopes provide new insights into mercury toxicokinetics in pilot whales. Sci. Tot. Environ. 2020, 710, n 136325.

(17) Sherman, L. S.; Blum, J. D.; Franzblau, A.; Basu, N. New insight into biomarkers of human mercury exposure using naturally occurring mercury stable isotopes. Environ. Sci. Technol. 2013, 47, 3403-3409.

(18) Ma, L.; Evans, R. D.; Wang, W.; Georg, R. B. In vivo fractionation of mercury isotopes in tissues of a mammalian carnivore (Neovison vison). Sci. Tot. Environ. 2018, 627, 1228-1233.

(19) Masbou, J.; Sonke, J. E.; Amouroux, D.; Guillou, G.; Becker, P. R.; Point, D. Hg-stable isotope variations in marine top predators of the western Arctic Ocean. ACS Earth Space Chem. 2018, 2, 479490.

(20) Schauble, E. A. Role of nuclear volume in driving equilibrium stable isotope fractionation of mercury, thallium, and other very heavy elements. Geochim. Cosmichim. Acta 2007, 71, 2170-2189.

(21) Wiederhold, J. G.; Cramer, C. J.; Daniel, K.; Infante, I.; Bourdon, B.; Kretzschmar, R. Equilibrium mercury isotope fractionation between dissolved $\mathrm{Hg}(\mathrm{II})$ species and thiol-bound $\mathrm{Hg}$. Environ. Sci. Technol. 2010, 44, 4191-4197.

(22) Ghosh, S.; Schauble, E. A.; Couloume, G. L.; Blum, J. D.; Bergquist, B. A. Estimation of nuclear volume dependent fractionation of mercury isotopes in equilibrium liquid-vapor evaporation experiments. Chem. Geol. 2013, 336, 5-12. 
(23) Blum, J. D.; Drazen, J. C.; Johnson, M. W.; Popp, B. N.; Motta, L. C.; Jamieson, A. J. Mercury isotopes identify near-surface marine mercury in deep-sea trench biota. Proc. Natl. Acad. Sci. U. S. A. 2020, 117, 29292-29298.

(24) Masbou, J.; Point, D.; Sonke, J. E.; Frappart, F.; Perrot, V.; Amouroux, D.; Richard, P.; Becker, P. R. Hg stable isotope time trend in ringed seals registers decreasing sea ice cover in the Alaskan Arctic. Environ. Sci. Technol. 2015, 49, 8977-8985.

(25) Kwon, S. Y.; Blum, J. D.; Yin, R.; Tsui, M. T. K.; Yang, Y. H.; Choi, J. W. Mercury stable isotopes for monitoring the effectiveness of the Minamata Convention on Mercury. Earth Sci. Rev. 2020, 203, 22.

(26) Lepak, R. F.; Hoffman, J. C.; Janssen, S. E.; Krabbenhoft, D. P.; Ogorek, J. M.; DeWild, J. F.; Tate, M. T.; Babiarz, C. L.; Yin, R. S.; Murphy, E. W.; Engstrom, D. R.; Hurley, J. P. Mercury source changes and food web shifts alter contamination signatures of predatory fish from Lake Michigan. Proc. Natl. Acad. Sci. U. S. A. 2019, 116, 23600-23608.

(27) Rosera, T. J.; Janssen, S. E.; Tate, M. T.; Lepak, R. F.; Ogorek, J. M.; DeWild, J. F.; Babiarz, C. L.; Krabbenhoft, D. P.; Hurley, J. P. Isolation of methylmercury using distillation and anion-exchange chromatography for isotopic analyses in natural matrices. Anal. Bioanal. Chem. 2020, 412, 681-690.

(28) Janssen, S. E.; Lepak, R. F.; Tate, M. T.; Ogorek, J. M.; DeWild, J. F.; Babiarz, C. L.; Hurley, J. P.; Krabbenhoft, D. P. Rapid pre-concentration of mercury in solids and water for isotopic analysis. Anal. Chim. Acta, 2019, 1054, 95-103.

(29) Yin, R. S.; Krabbenhoft, D. P.; Bergquist, B. A.; Zheng, W.; Lepak, R. F.; Hurley, J. P. Effects of mercury and thallium concentrations on high precision determination of mercury isotopic composition by Neptune Plus multiple collector inductively coupled plasma mass spectrometry. $J$. Anal. At. Spectrom. 2016, 31, 2060-2068.

(30) Poulin, B. A.; Janssen, S. E.; Rosera, T. J. Mercury and methylmercury stable isotope measurements in giant petrels. U.S. Geological Survey Data Release 2021, DOI: 10.5066/P9UEG9Q1.

(31) Tarantola, A. Inverse Problem Theory and Methods for Model Parameter Estimation. Society for Industrial and Applied Mathematics, Philadelphia: 2005; p 342.

(32) Manceau, A.; Brossier, R.; Janssen, S. E.; Rosera, T. J.; Krabbenhoft, D. P.; Cherel, Y.; Bustamante, P.; Poulin, B. A. Inversion. GRICAD GitLab 2021, https://gricad-gitlab.univ-grenoblealpes.fr/mercury_inversion/inversion_3species.

(33) Renedo, M.; Amouroux, D.; Duval, B.; Carravieri, A.; Tessier, E.; Barre, J.; Berail, S.; Pedrero, Z.; Cherel, Y.; Bustamante, P. Seabird tissues as efficient biomonitoring tools for $\mathrm{Hg}$ isotopic investigations: Implications of using blood and feathers from chicks and adults. Environ. Sci. Technol. 2018, 52, 4227-4234.

(34) Bergquist, B. A.; Blum, J. D. Mass-dependent and -independent fractionation of $\mathrm{Hg}$ isotopes by photoreduction in aquatic systems. Science 2007, 318, 417-420.

(35) Tsui, M. T. K.; Blum, J. D.; Kwon, S. Y. Review of stable mercury isotopes in ecology and biogeochemistry. Sci. Tot. Environ. $2020,716$.

(36) Asaduzzaman, A.; Schreckenbach, G. Degradation mechanism of methyl mercury selenoamino acid complexes: A computational study. Inorg. Chem. 2011, 50, 2366-2372. 
(37) Wang, Q.; Zhang, C. X.; Ren, Y. S.; Yue, W. B.; Shi, L. G.; Lei, F. L. Molecular structure, expression analysis and functional characterization of selenoprotein P (SEPP1) in goat (Capra hircus). J. Anim. Vet. Adv. 2012, 11, 2898-2904.

(38) Hill, K. E.; Wu, S.; Motley, A. K.; Stevenson, T. D.; Winfrey, V. P.; Capecchi, M. R.; Atkins, J. F.; Burk, R. F. Production of selenoprotein P (Sepp1) by hepatocytes is central to selenium homeostasis. J. Biol. Chem. 2012, 287, 40414-40424.

(39) Betz, A. L.; Goldstain, G. W. Polarity of the blood-brain barrier: Neutral amino acid transport into isolated brain capillaries. Science 1978, 202, 225-227.

(40) Cheesman, B. V.; Arnold, A. P.; Rabenstein, D. L. Nuclear magnetic resonance studies of the solution chemistry of metal Complexes. 25 . $\mathrm{Hg}$ (thiol $)_{3}$ complexes and $\mathrm{Hg}$ (II)-thiol ligand exchange kinetics. J. Am. Chem. Soc. 1988, 110, 6359-6364.

(41) Hill, K. E.; Lloyd, R. S.; Burk, R. F. Conserved nucleotide-sequences in the open reading frame and 3' untranslated region of selenoprotein-P messenger-RNA. Proc. Natl. Acad. Sci. U. S. A. 1993, 90, 537-541.

(42) Yang, X. G.; Hill, K. E.; Maguire, M. J.; Burk, R. F. Synthesis and secretion of selenoprotein P by cultured rat astrocytes. Biochim. Biophys. Acta 2000, 1474, 390-396.

(43) Scharpf, M.; Schweizer, U.; Arzberger, T.; Roggendorf, W.; Schomburg, L.; Kohrle, J. Neuronal and ependymal expression of selenoprotein P in the human brain. J. Neural Transm. 2007, 114, 877884.

(44) Hoffmann, P. R.; Hoge, S. C.; Li, P. A.; Hoffmann, F. W.; Hashimoto, A. C.; Berry, M. J. The selenoproteome exhibits widely varying, tissue-specific dependence on selenoprotein $\mathrm{P}$ for selenium supply. Nucleic Acids Res. 2007, 35, 3963-3973.

(45) Burk, R. F.; Hill, K. E. Selenoprotein P-Expression, functions, and roles in mammals. BBA-Gen. Subjects 2009, 1790, 1441-1447.

(46) Burk, R. F.; Hill, K. E.; Olson, G. E.; Weeber, E. J.; Motley, A. K.; Winfrey, V. P.; Austin, L. M. Deletion of apolipoprotein E receptor-2 in mice lowers brain selenium and causes severe neurological dysfunction and death when a low-selenium diet is fed. J. Neurosci. 2007, 27, 6207-6211.

(47) Olson, G. E.; Winfrey, V. P.; Hill, K. E.; Burk, R. F. Megalin mediates selenoprotein P uptake by kidney proximal tubule epithelial cells. J. Biol. Chem. 2008, 283, 6854-6860.

(48) Krol, M. B.; Gromadzinska, J.; Wasowicz, W. SeP, ApoER2 and megalin as necessary factors to maintain Se homeostasis in mammals. J. Trace Elem. Med. Biol. 2012, 26, 262-266.

(49) Burk, R. F.; Hill, K. E. Regulation of selenium metabolism and transport. In Annu. Rev. Nutr., Bowman, B. A.; Stover, P. J., Eds. 2015; Vol. 35, pp 109-134.

(50) Achouba, A.; Dumas, P.; Ouellet, N.; Lemire, M.; Ayotte, P. Plasma levels of seleniumcontaining proteins in Inuit adults from Nunavik. Environ. Intern. 2016, 96, 8-15.

(51) Laffont, L.; Sonke, J. E.; Maurice, L.; Hintelmann, H.; Pouilly, M.; Bacarreza, Y. S.; Perez, T.; Behra, P. Anomalous mercury isotopic compositions of fish and human hair in the Bolivian Amazon. Environ. Sci. Technol. 2009, 43, 8985-8990.

(52) Perrot, V.; Pastukhov, M. V.; Epov, V. N.; Husted, S.; Donard, O. F. X.; Amouroux, D. Higher mass-independent isotope fractionation of methylmercury in the pelagic food web of Lake Baikal (Russia). Environ. Sci. Technol. 2012, 46, 5902-5911. 
(53) Manceau, A.; Brossier, R.; Poulin, B. A. Alternating inversion. GRICAD GitLab 2021, https://gricad-gitlab.univ-grenoble-alpes.fr/mercury_inversion/alternating_inversion.

\section{ASSOCIATED CONTENT \\ Supporting Information}

Description of mass-independent fractionation analysis, supplementary figures S1-S7 (PDF).

Python code of the inversion software (Inv3-202Hg) (txt)

ReadMe of Inv3-202Hg (txt)

Input files of Inv3-202Hg (tx)

Input dataset (csv)

\section{AUTHOR INFORMATION}

ORCID

Alain Manceau: 0000-0003-0845-611X

Romain Brossier: 0000-0002-7195-8123

Sarah E. Janssen: 0000-0003-4432-3154

David P. Krabbenhoft: 0000-0003-1964-5020

Yves Cherel: 0000-0001-9469-9489

Paco Bustamante: 0000-0003-3877-9390

Brett A. Poulin: 0000-0002-5555-7733

\section{Notes}

The authors declare no competing financial interests.

\section{ACKNOWLEDGMENTS}

Support was provided to Alain Manceau by the ANR under grant ANR-10-EQPX-27-01 (EcoX Equipex), to Brett A. Poulin by the U.S. National Science Foundation under grant EAR-1629698, to Brett A. Poulin, Sarah E. Janssen, and David P. Krabbenhoft by the U.S. Geological Survey (USGS) Environmental Health Mission Area's Toxic Substances Hydrology and Contaminants Biology Programs, to Paco Bustamante and Yves Cherel by the Institut Polaire Français Paul Emile Victor (IPEV programme no. 109, C. Barbraud) and the Terres Australes et Antarctiques Francaises, and to Paco Bustamante by the Institut Universitaire de France (IUF). We thank Ryan Lepak (U.S. Environmental Protection Agency) and three anonomous reviewers for constructive comments on the manuscript. Any use of trade, firm, or product names is for descriptive purposes only and does not imply endorsement by the U.S. Government.

\section{LEGENDS TO FIGURES}

Figure 1. Ternary plot of the proportions of $\mathrm{MeHg}, \mathrm{Hg}(\mathrm{Sec})_{4}$, and $\mathrm{HgSe}$ in the liver (L, black), kidneys (K, blue), muscle (M, purple), and feathers ( $\mathrm{F}$, red) of five individuals (P1-P5), and the brain (B, green) of three other individuals (P6-P8), of giant petrels, as obtained by HR-XANES. ${ }^{7}$ 
Figure 2. Bar charts of $\delta^{202} \mathrm{Hg}_{t}$ values of feathers (red), kidneys (blue), liver (black), and muscle (purple) tissues of five giant petrels (P1-P5) and brain tissues (green) of three additional giant petrels (P6-P8). Error bars present $\pm 1 \mathrm{SD}$ of isotope measurements (Table S2) and analytical precision in $\delta^{202} \mathrm{Hg}$ of certified reference materials is provided in Table S5. The high $\delta^{202} \mathrm{Hg}_{t}$ values of feathers are due to the exclusive presence of $\mathrm{MeHg}\left(\delta^{202} \mathrm{MeHg}=2.69 \pm 0.04 \%\right.$ o $)$. Muscle tissues exhibit lower $\delta^{202} \mathrm{Hg}_{t}$ values than liver tissues because muscle tissues contain a higher proportion of isotopically distinct $\mathrm{Hg}(\mathrm{Sec})_{4}\left(\delta^{202} \mathrm{Hg}(\mathrm{Sec})_{4}=-1.37 \pm 0.06 \%\right.$ ) and the liver tissues contain primarily $\mathrm{HgSe}$ $\left(\delta^{202} \mathrm{HgSe}=0.18 \pm 0.02 \%\right)$.

Figure 3. Relationship between $\delta^{202} \mathrm{Hg}_{t}$ and $f(\mathrm{MeHg})$ of giant petrel tissues $(n=23,1 \mathrm{SD})$. The solid black line presents the linear regression between $\delta^{202} \mathrm{Hg}_{t}$ and $f(\mathrm{MeHg})$ excluding the muscle data (slope 2.6, y-intercept of $0.0 \%$, and a Pearson correlation $R^{2}=0.98$ ). The dashed black line is the linear regression between $\delta^{202} \mathrm{Hg}_{t}$ and $f(\mathrm{MeHg})$ including the muscle data $\left(R^{2}=0.91\right)$. Error bars present uncertainties in $f\left(\mathrm{MeHg}\right.$ ) from HR-XANES fits ${ }^{7}$ and $\pm 1 \mathrm{SD}$ of isotope measurements (Table S2), and analytical precision in $\delta^{202} \mathrm{Hg}$ of certified reference materials is provided in Table S5. Methylmercury is completely demethylated in the liver and almost completely demethylated in muscle and kidneys. The large variability in $\delta^{202} \mathrm{Hg}_{t}$ for the same $f(\mathrm{MeHg})$ at $f(\mathrm{MeHg}) \leq 0.1$ results from the coexistence of two inorganic species, $\mathrm{Hg}(\mathrm{Sec})_{4}$ and $\mathrm{HgSe}$, with contrasted species-specific $\delta^{202} \mathrm{Hg}$ values.

Figure 4. Calculated versus measured species-averaged values of $\delta^{202} \mathrm{Hg}\left(\delta^{202} \mathrm{Hg}_{\text {calc }}\right.$ versus $\delta^{202} \mathrm{Hg}_{t}$, respectively) in the giant petrel tissues $(n=23)$. Error bars present \pm 1 SD of isotope values (Table S2). The solid black, dashed gray, and dotted gray lines present the linear fit, 95\% confidence intervals of the fit, and prediction intervals of the fit, respectively. The outlier kidney of individual P5 (identified by the black arrow) was omitted in the calculation of the regression line $\left(\delta^{202} \mathrm{Hg}_{\text {calc }}=0.972 \times \delta^{202} \mathrm{Hg}_{t}\right.$ $\left.+0.007, \mathrm{R}^{2}=0.983\right)$.

Figure 5. Schematic diagram showing the isotopic fractionation of ${ }^{202} \mathrm{Hg}$ due to the $\mathrm{MeHgCys} \rightarrow$ $\mathrm{Hg}(\mathrm{Sec})_{4} \rightarrow \mathrm{HgSe}$ demethylation and biomineralization reactions (left panel), and diagrammatic representation of the proportions of $\mathrm{MeHgCys}, \mathrm{Hg}(\mathrm{Sec})_{4}$, and $\mathrm{HgSe}$ in the tissues of giant petrels (expressed as the percentage of total $\mathrm{Hg}$ ), and of the species-specific and species-averaged $\delta^{202} \mathrm{Hg}$ values (right panel). 


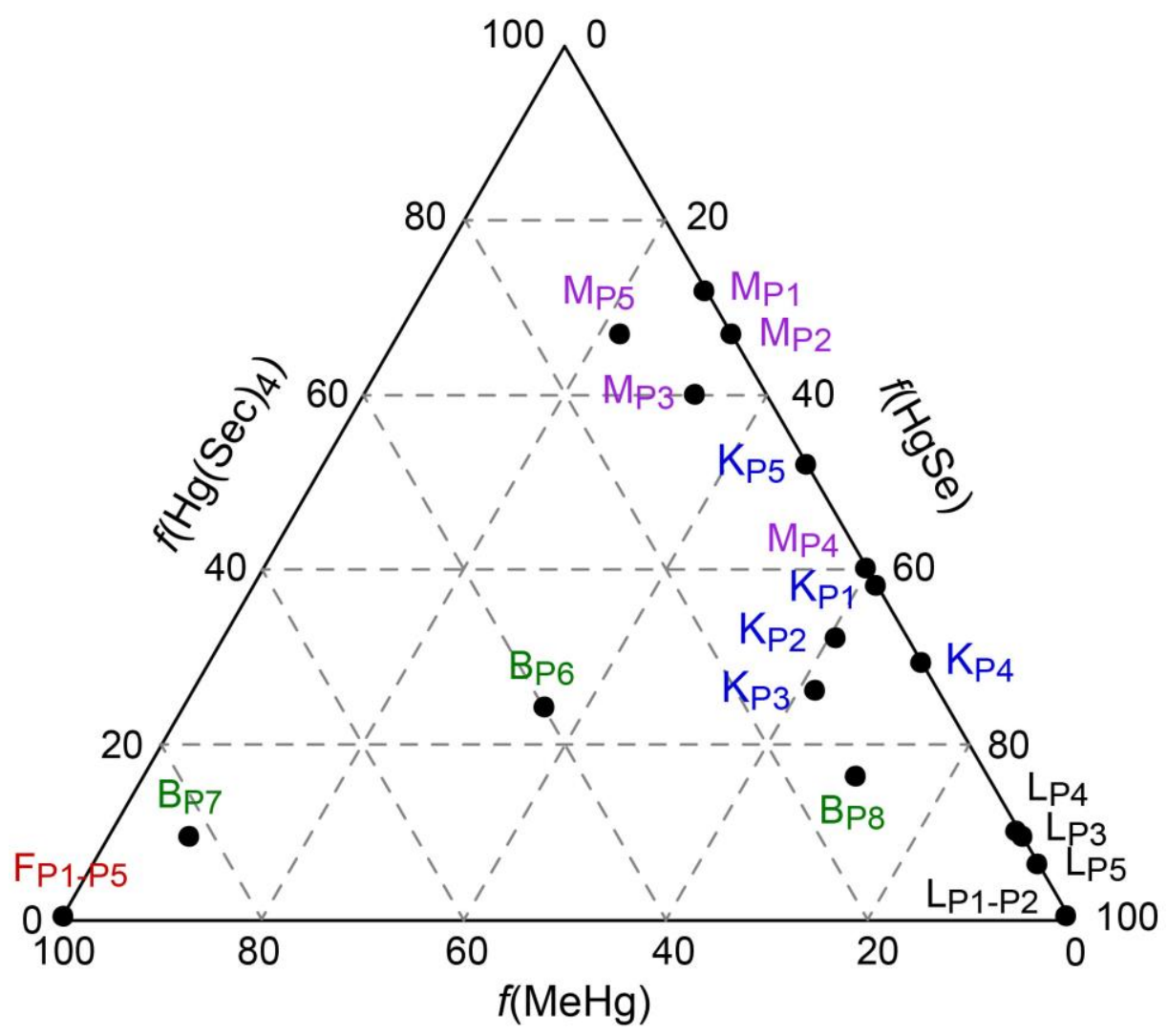

Figure 1 


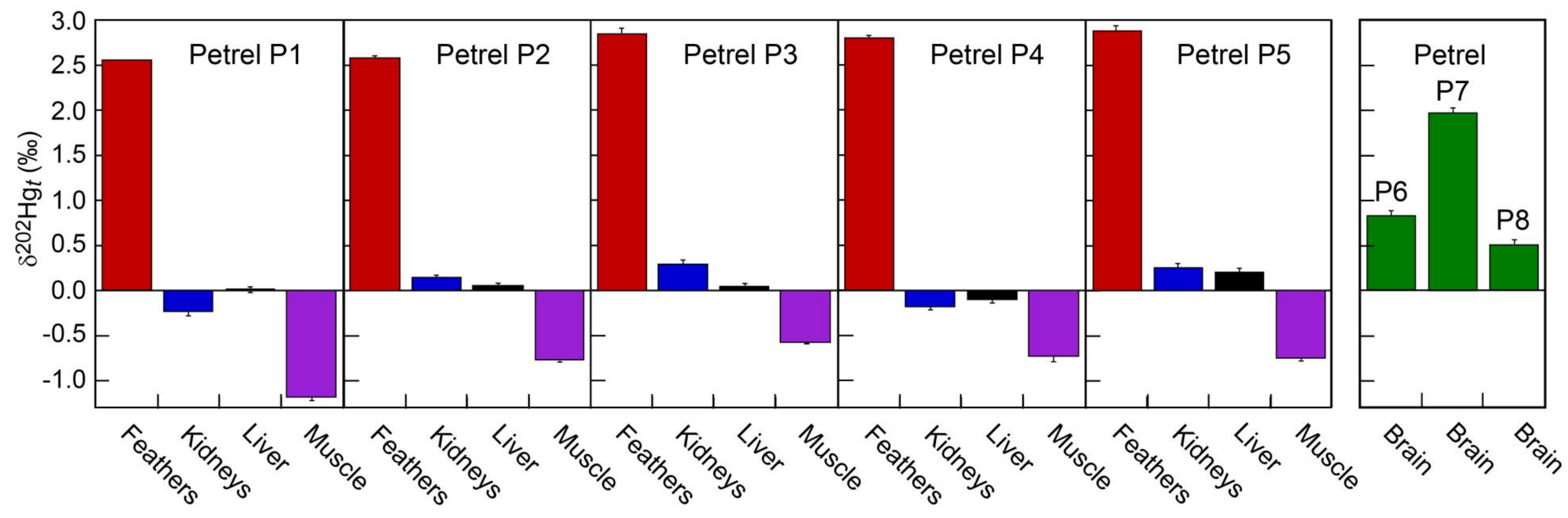

Figure 2 


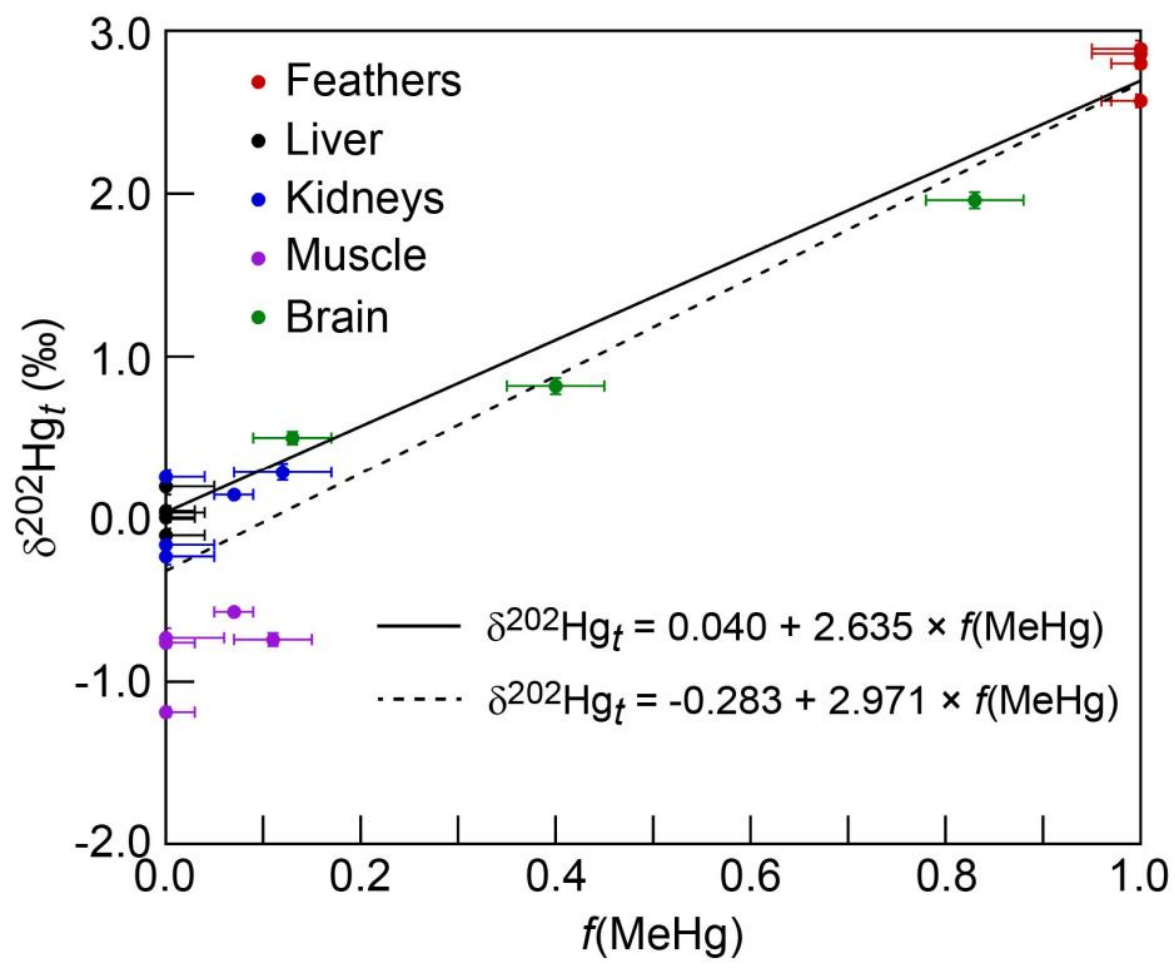

Figure 3 


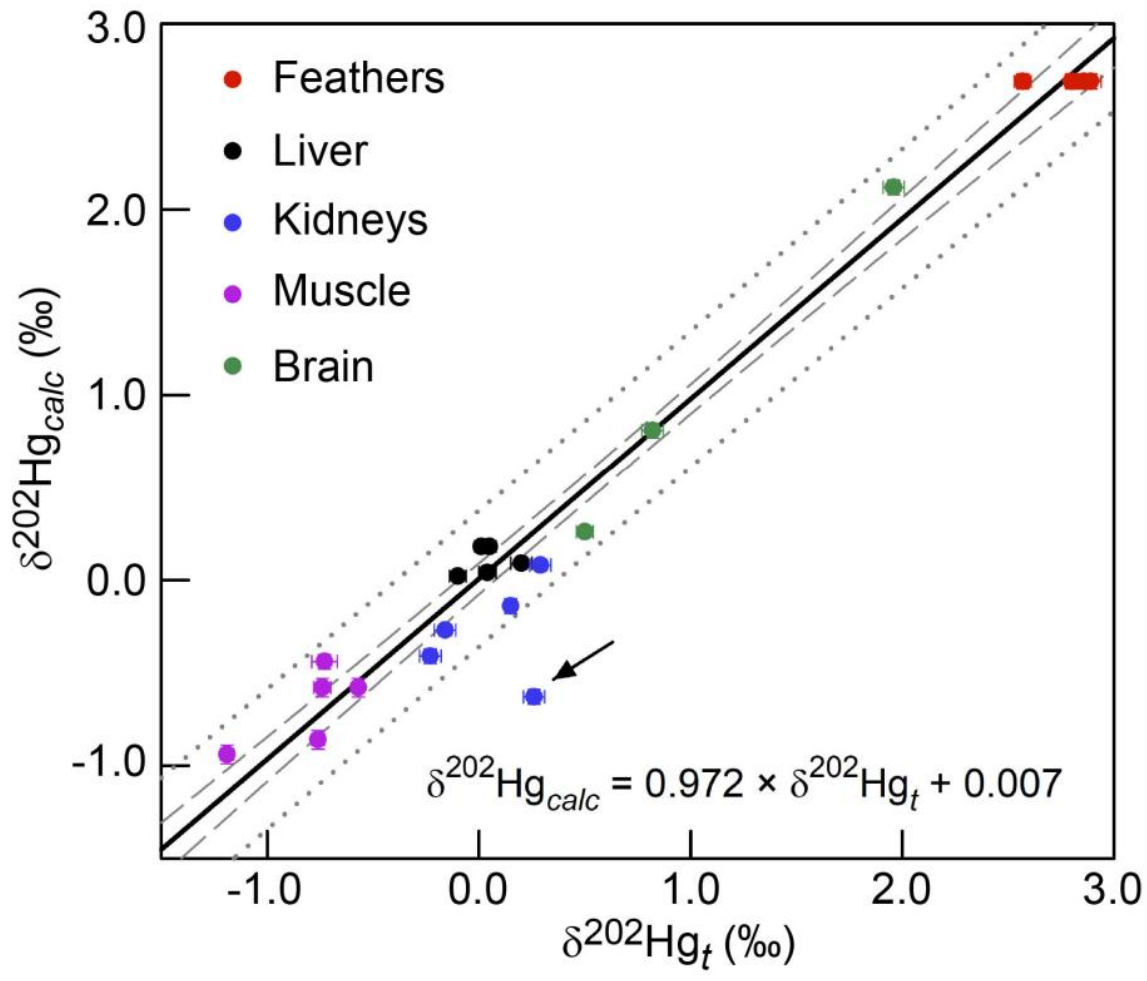

Figure 4 
Species-specific fractionation

$\delta^{202 \mathrm{MeHg}}=2.69 \pm 0.04 \%$

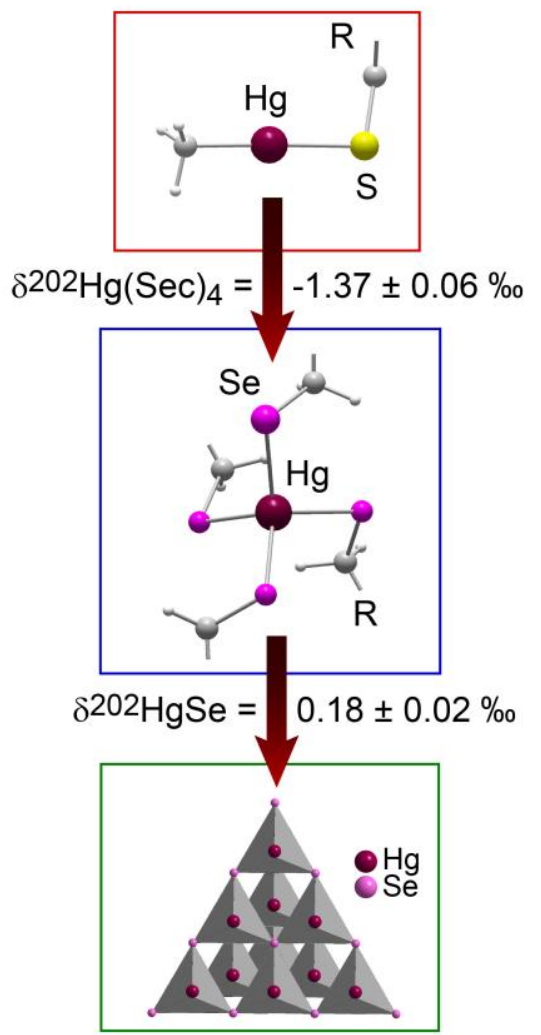

Species-averaged fractionation

$\delta 202 \mathrm{Hgb}=1.09 \pm 0.77 \%$

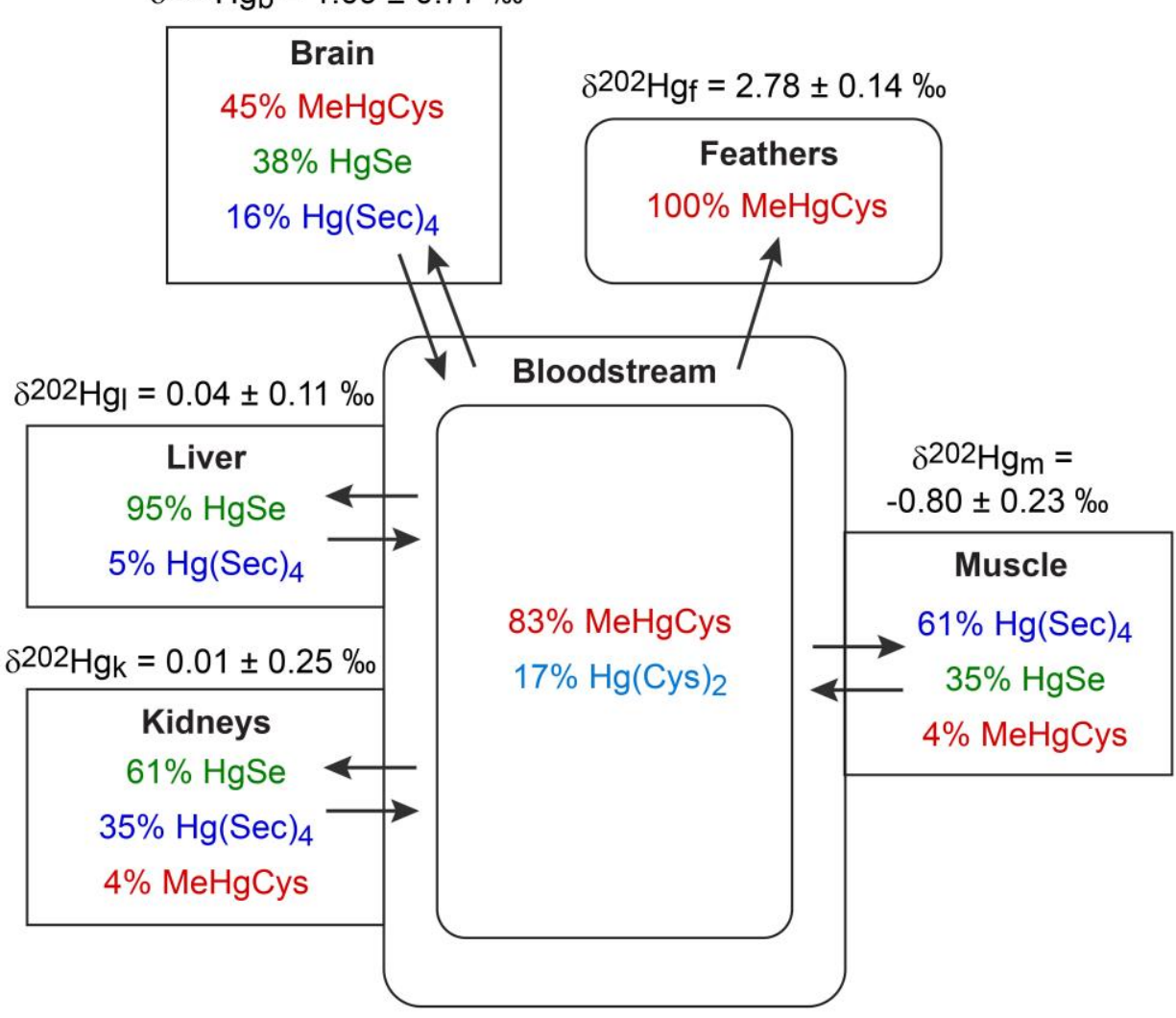

Figure 5 


\title{
Supporting Information
}

\section{Mercury isotope fractionation by internal demethylation and biomineralization reactions in seabirds: implications for environmental mercury science}

\author{
Alain Manceau, ${ }^{1,}$ Romain Brossier, ${ }^{1}$ Sarah E. Janssen, ${ }^{2}$ Tylor J. Rosera, ${ }^{2}$ David P. Krabbenhoft, ${ }^{2}$ \\ Yves Cherel, ${ }^{3}$ Paco Bustamante, ${ }^{4}$ and Brett A. Poulin ${ }^{5, *}$ \\ ${ }^{1}$ Université Grenoble Alpes, ISTerre, CNRS, 38000 Grenoble, France \\ ${ }^{2}$ U.S. Geological Survey, Upper Midwest Water Science Center, Middleton, WI, 53562, USA \\ ${ }^{3}$ Centre d'Etudes Biologiques de Chizé (CEBC), CNRS, La Rochelle Université, 79360 Villiers-en- \\ Bois, France \\ ${ }^{4}$ Littoral Environnement et Sociétés (LIENSs), CNRS-La Rochelle Université, 17000 La Rochelle, \\ France \\ ${ }^{5}$ Department of Environmental Toxicology, University of California Davis, Davis, CA 95616, \\ USA
}

* Corresponding authors. Email address: alain.manceau@univ-grenoble-alpes.fr (A. Manceau), bapoulin@ucdavis.edu (B.A. Poulin).

Supporting information includes 7 Figures, 5 Tables, and 11 pages.

Disclaimer: Any use of trade, firm, or product names is for descriptive purposes only and does not imply endorsement by the U.S. Government.

\section{Mass-Independent Fractionation (MIF) Analysis}

The MIF of mercury ( $\mathrm{Hg}$ ) isotopes was evaluated in gient petrels (Macronectes spp.) P1-P5 for the mercury-tetraselenolate complex $\left(\mathrm{Hg}(\mathrm{Sec})_{4}\right) \rightarrow$ mercury selenide $(\mathrm{HgSe})$ biomineralization reaction. Changes in $\Delta^{199} \mathrm{Hg}$ and $\Delta^{201} \mathrm{Hg}$ were calculated for each bird (Table S4). First, "initial" $\Delta{ }^{199} \mathrm{Hg}$ and $\Delta^{201} \mathrm{Hg}$ values were assigned for each petrel. Previous high energy-resolution X-ray absorption nearedge structure (HR-XANES) spectroscopy and species-specific isotope measurement of birds from diverse aquatic systems demonstrate that the demethylation reaction of methylmercury into mercury tetraselenolate $\left((\mathrm{MeHg}) \rightarrow \mathrm{Hg}(\mathrm{Sec})_{4}\right)$ does not induce mass independent fractionation (MIF). ${ }^{1}$ Therefore, the "initial" $\Delta{ }^{199} \mathrm{Hg}$ and $\Delta^{201} \mathrm{Hg}$ values were assigned for each individual using isotope values of feathers (which contained exclusively MeHg, Table S2) or the mean of feather values and values of MeHg extracted from tissues. The $\Delta^{199} \mathrm{Hg}$ and $\Delta^{201} \mathrm{Hg}$ values of the $\mathrm{MeHg}$ pool were assumed to be integrated across tissues and be representative of $\mathrm{MeHg}$ during the adult life of the bird. The specific tissues used to establish the "initial" $\Delta^{199} \mathrm{Hg}$ and $\Delta^{201} \mathrm{Hg}$ values are provided in Table S4. Next, $\Delta^{199} \mathrm{Hg}$ and $\Delta^{201} \mathrm{Hg}$ values of $\mathrm{HgSe}$ were assigned for each petrel using isotope values of liver tissues, which contained nearly exclusively mercury selenide $(0.90 \leq f(\mathrm{HgSe} \leq 1.00)$. The $\mathrm{Hg}(\mathrm{Sec}) 4 \rightarrow \mathrm{HgSe}$ biomineralization reaction is nearly complete in the liver of the petrels, and therefore difference in 
$\Delta^{199} \mathrm{Hg}$ and $\Delta^{201} \mathrm{Hg}$ values between the "initial" $\mathrm{MeHg}$ and liver were calculated. As shown in Table $\mathrm{S} 4$, the $\mathrm{Hg}(\mathrm{Sec})_{4} \rightarrow \mathrm{HgSe}$ biomineralization reaction resulted in decreases in $\Delta^{199} \mathrm{Hg}$ values by -0.10 to $-0.32 \%$ and $\Delta^{201} \mathrm{Hg}$ values by -0.06 to $-0.21 \%$, respectively. Differences in $\Delta^{199} \mathrm{Hg}$ and $\Delta^{201} \mathrm{Hg}$ values exceeded the analytical precision (Table S5, Figure S7). The ratio of the difference in $\Delta^{199} \mathrm{Hg}$ to difference in $\Delta^{201} \mathrm{Hg}\left(\Delta^{199} \mathrm{Hg} / \Delta^{201} \mathrm{Hg}\right)$ between $\mathrm{MeHg}$ and $\mathrm{HgSe}$, which is interpreted to represent the slope of change in $\Delta^{199} \mathrm{Hg}$ to $\Delta^{201} \mathrm{Hg}$ for the internal $\mathrm{Hg}(\mathrm{Sec})_{4} \rightarrow \mathrm{HgSe}$ biomineralization reaction, averaged $1.6 \pm 0.3$ (average \pm standard deviation, $n=5$; ranged from 1.10 to 1.93) and was in good agreement with the measured $(\sim 1.54 \pm 0.22)$ and theoretical $(1.65)$ ratio for nuclear volume effect $(\mathrm{NVE})^{2}$

All $\mathrm{Hg}$ isotope data collected as part of this study is available as part of a supplementary data release. ${ }^{10}$

\section{Supplementary Figures}

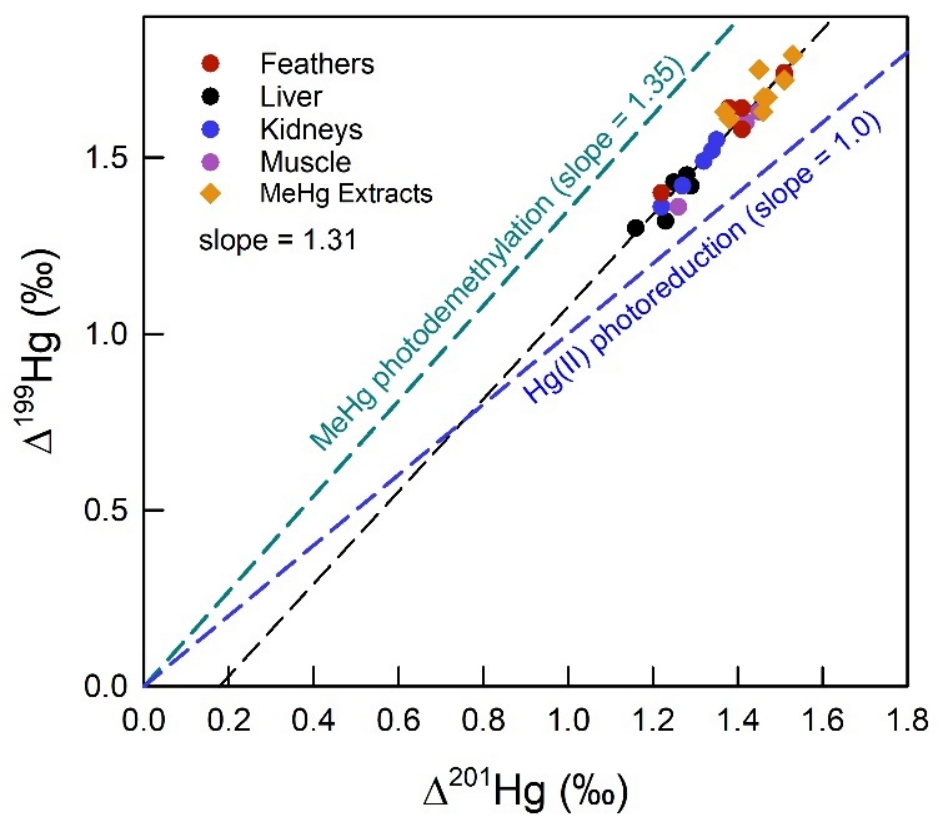

Figure S1. Odd mass-independent fractionation (MIF) isotope values $\left(\Delta^{199} \mathrm{Hg}\right.$ vs $\left.\Delta^{201} \mathrm{Hg}\right)$ of total $\mathrm{Hg}$ digests of giant petrel tissues $(n=20)$ and $\mathrm{MeHg}$ extracts of selected tissues $(n=9)$. The dashed gray line presents the fit of the data. Dashed blue and green lines present empirical slopes for residual $\mathrm{Hg}$ (II) photoreduction and residual $\mathrm{MeHg}$ photodemethylation processes in water, ${ }^{3}$ respectively. Analytical precision in $\Delta^{199} \mathrm{Hg}$ and $\Delta{ }^{201} \mathrm{Hg}$ values of certified reference materials is provided in Table S5. An outlier $\left(\mathrm{P} 5\right.$, muscle, $\Delta^{199} \mathrm{Hg}=1.98 \pm 0.01 \%$ o, $\Delta{ }^{201} \mathrm{Hg}$ $=1.33 \pm 0.01 \%$ ) was identified based on deviation in the $\Delta^{199} \mathrm{Hg}$ versus $\Delta^{201} \mathrm{Hg}$ regression and is neither shown in the figure nor included in the regression. 

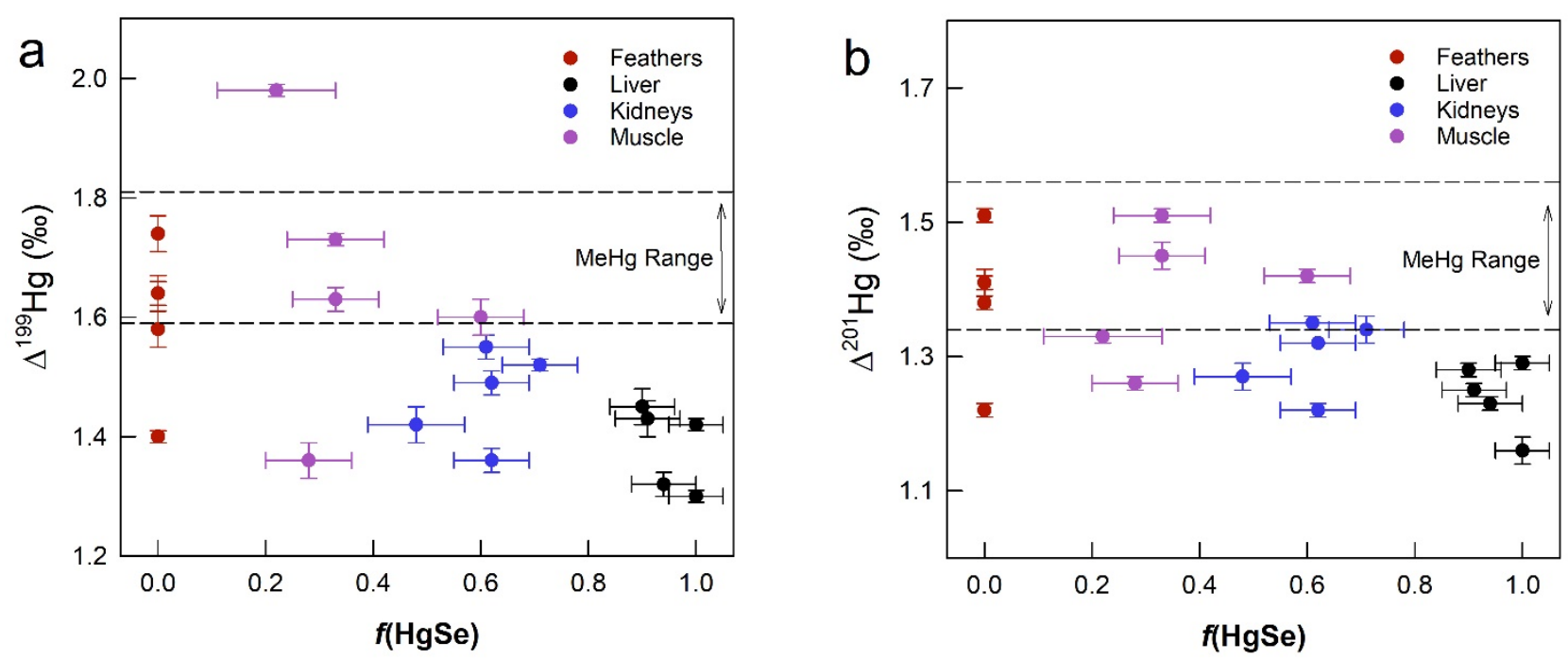

Figure S2. Scatter plot showing the (a) $\Delta^{199} \mathrm{Hg}$ and (b) $\Delta^{201} \mathrm{Hg}$ values versus the fraction of $\mathrm{HgSe}(f(\mathrm{HgSe}))$ of giant petrel feathers and tissues with respect to the range of $\mathrm{MeHg}$ (dashed black lines). Differences in $\Delta^{199} \mathrm{Hg}$ and $\Delta^{201} \mathrm{Hg}$ values between samples with $f(\mathrm{HgSe})=0$ (feathers, and MeHg extracts, $\left.n=10\right)$ and kidney and liver tissues $(0.48 \leq f(\mathrm{HgSe}) \leq 1.00 ; n=10)$ were of statistical significance $(p<0.001$; student's t-test). Vertical error bars present \pm 1 standard deviation (SD) of isotope values and horizontal error bars present uncertainties in $f(\mathrm{HgSe})$. An outlier sample ( $\mathrm{P} 5$, muscle) was identified based on deviation in the $\Delta^{199} \mathrm{Hg}$ versus $\Delta^{201} \mathrm{Hg}$ regression, but is shown here for completeness. Analytical precision in $\Delta^{199} \mathrm{Hg}$ and $\Delta^{201} \mathrm{Hg}$ values of certified reference materials is provided in Table S5.
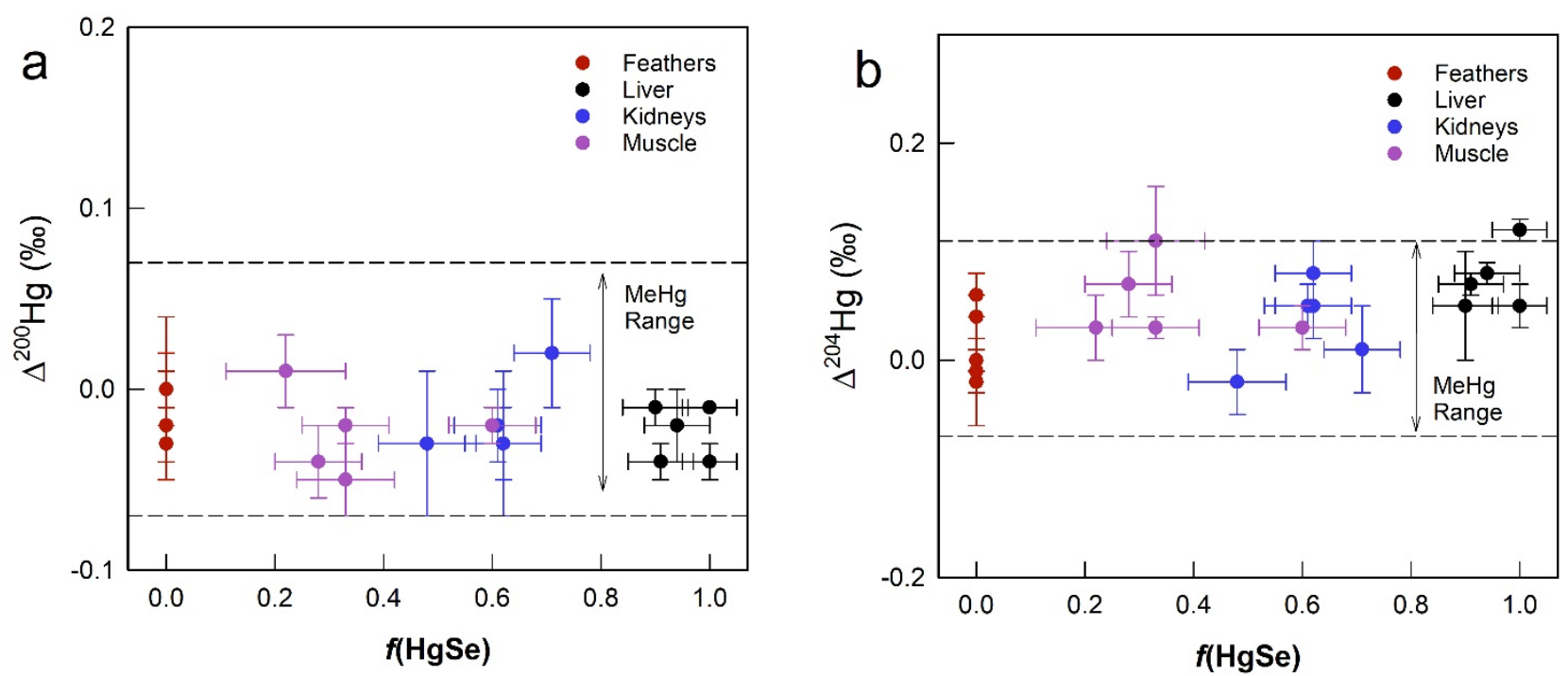

Figure S3. Scatter plot showing that the variability in (a) $\Delta^{200} \mathrm{Hg}$ and (b) $\Delta^{204} \mathrm{Hg}$ versus the fraction of $\mathrm{HgSe}$ $(f(\mathrm{HgSe}))$ of giant petrel feathers and tissues is within the range of $\mathrm{MeHg}$ (dashed black lines). Vertical error bars present $\pm 1 \mathrm{SD}$ of isotope values and horizontal error bars present uncertainties in $f(\mathrm{HgSe})$. Analytical precision in $\Delta^{200} \mathrm{Hg}$ and $\Delta^{204} \mathrm{Hg}$ values of certified reference materials are provided in Table S5. 


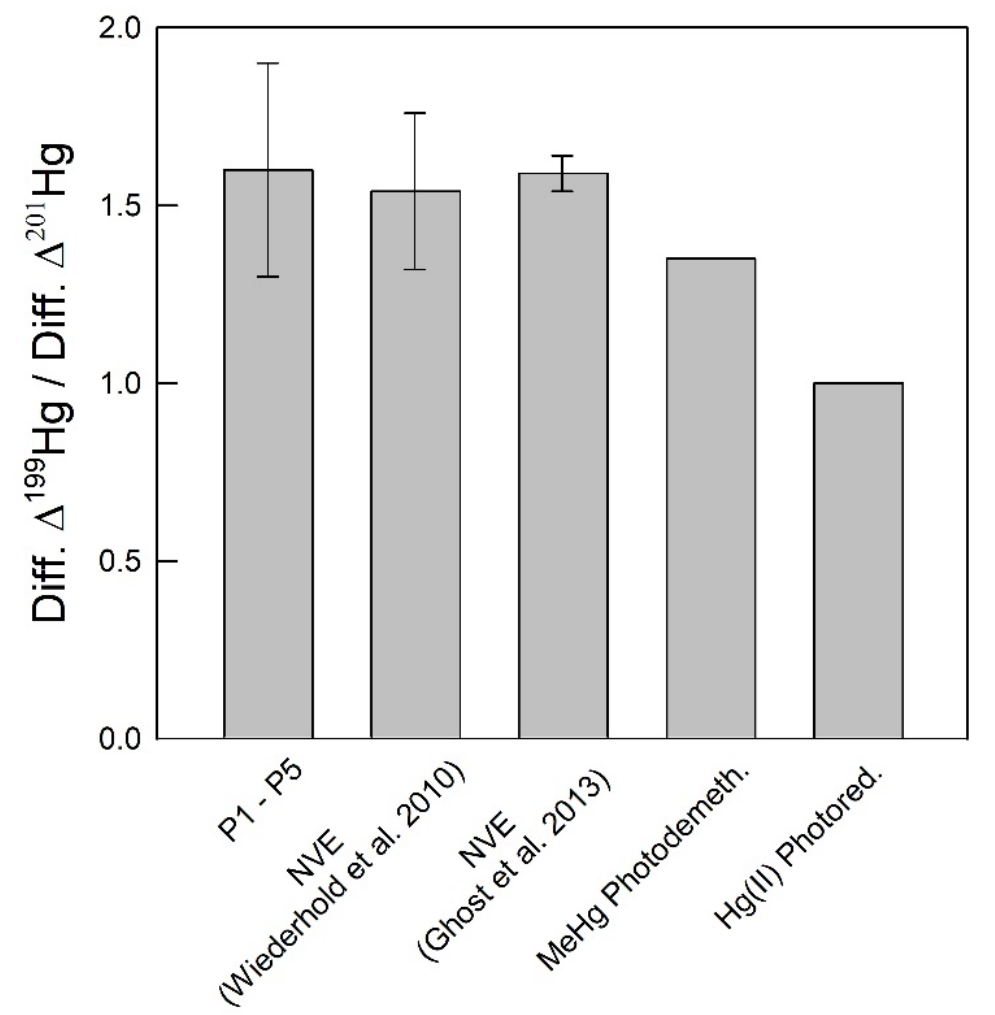

Figure S4. The ratio of the difference in $\Delta^{199} \mathrm{Hg}$ to difference in $\Delta^{201} \mathrm{Hg}$ (Diff. $\Delta{ }^{199} \mathrm{Hg}$ / Diff. $\Delta \Delta^{201} \mathrm{Hg}$ ) calculated between the MeHg pool and $\mathrm{HgSe}$ for giant petrels P1-P5 (average \pm standard deviation) and $\Delta^{199} \mathrm{Hg} / \Delta^{201} \mathrm{Hg}$ ratios induced by dark nuclear volume effect (NVE), ${ }^{2,}{ }^{4} \mathrm{MeHg}$ photodemethylation, and inorganic $\mathrm{Hg}(\mathrm{II})$ photoreduction. $^{3}$
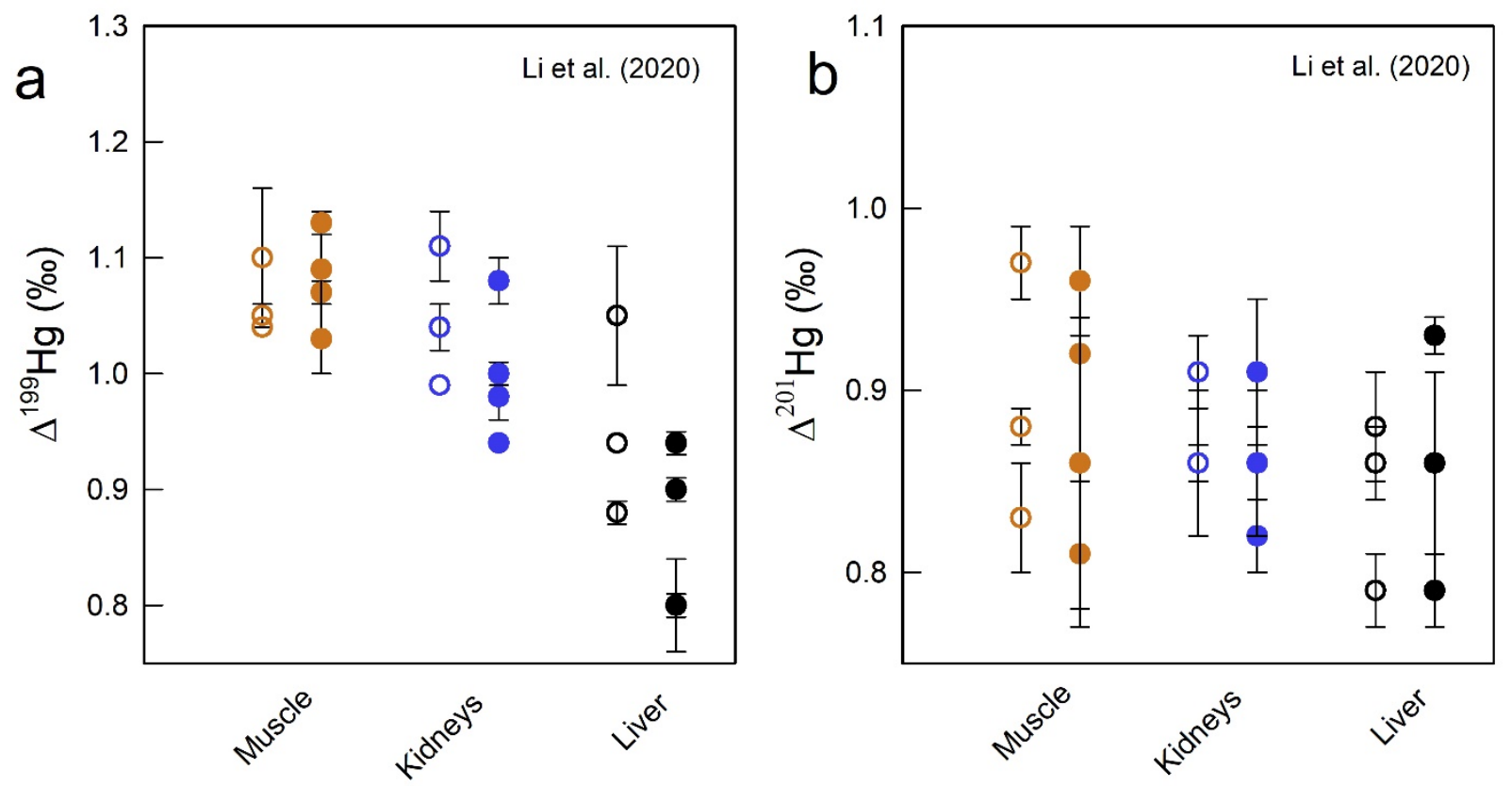
Figure S5. (a) $\Delta^{199} \mathrm{Hg}$ and (b) $\Delta{ }^{201} \mathrm{Hg}$ values of long-finned pilot whale (Globicephala melas) muscle, kidneys, and liver from Li et al. ${ }^{5}$. Open symbols are for juvenile whales and solid symbols are for adult whales. Error bars present $\pm 1 \mathrm{SD}$ of isotope values.

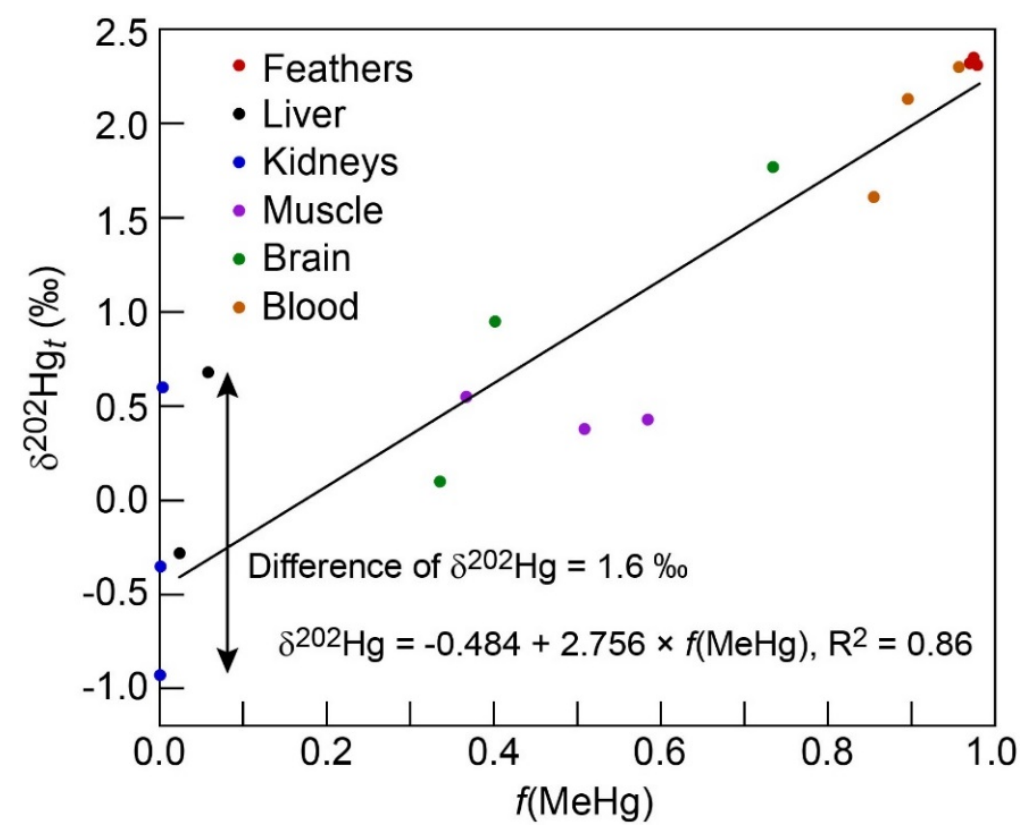

Figure S6. Plot of total $\mathrm{Hg}$ isotopes $\left(\delta^{202} \mathrm{Hg}_{t}\right)$ versus $f(\mathrm{MeHg})$ for giant petrel tissues analyzed by Renedo et al. ${ }^{6}$ The main difference between these data and data from this study (Figure 3 in the main text) is the higher $\delta^{202} \mathrm{Hg}_{t}$ and $f(\mathrm{MeHg})$ values of the muscle in the previous study, which indicates that $\mathrm{Hg}$ was less demethylated in the Renedo et al. ${ }^{6}$ giant petrel individuals than in the present individuals. The large variability (as great as $\sim 1.6 \%$ ) in $\delta^{202} \mathrm{Hg}_{t}$ of liver and kidneys observed at low $f(\mathrm{MeHg})$ is a strong indication for the coexistence of $\mathrm{Hg}(\mathrm{Sec})_{4}$ and $\mathrm{HgSe}$ in the two tissues. 

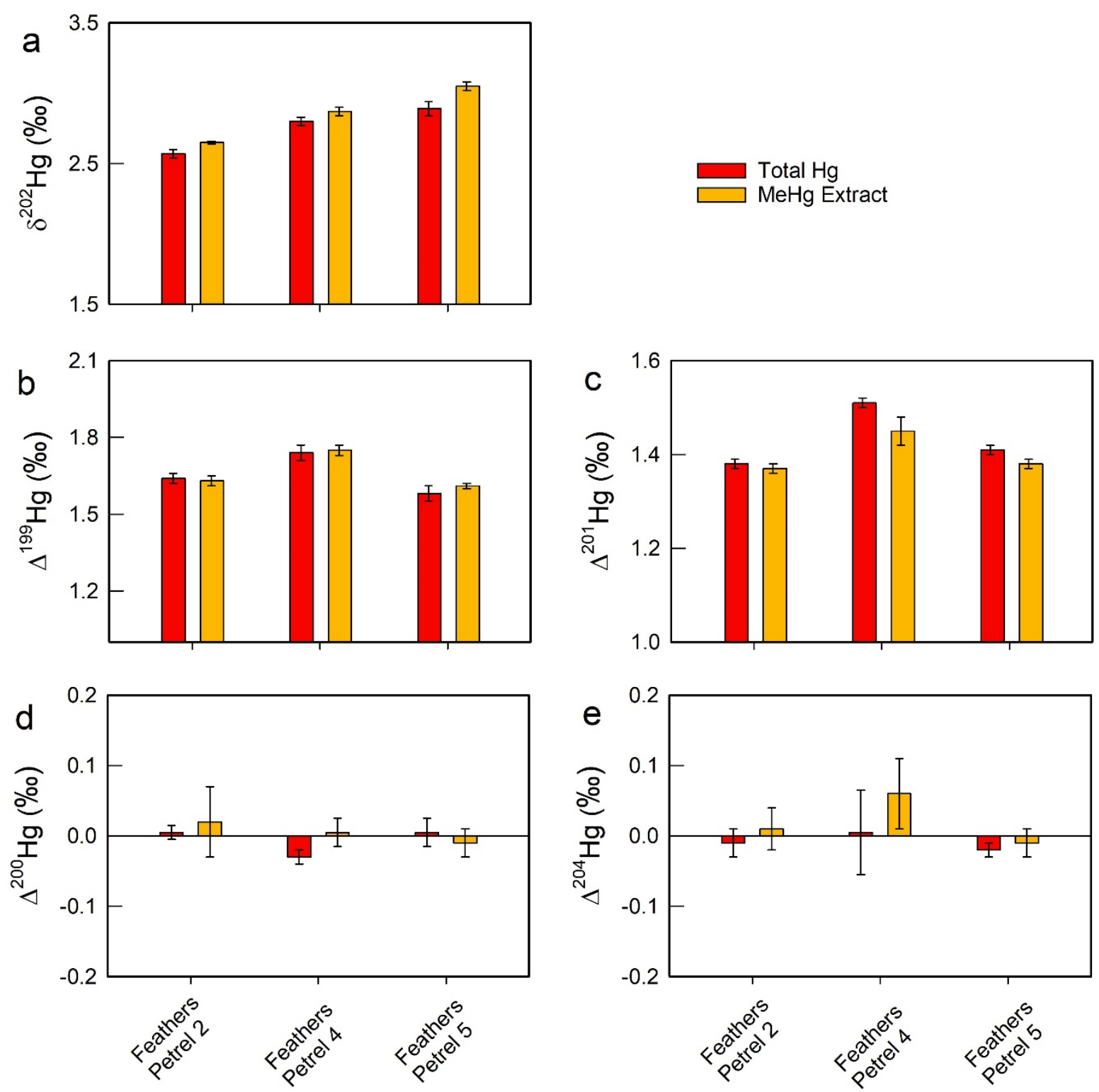

Figure S7. Stable mercury isotope values of (a) $\delta^{202} \mathrm{Hg}$, (b) $\Delta^{199} \mathrm{Hg}$, (c) $\Delta^{201} \mathrm{Hg}$, (d) $\Delta^{200} \mathrm{Hg}$, and (e) $\Delta^{204} \mathrm{Hg}$ of total $\mathrm{Hg}$ digests (red bars) and methylmercury ( $\mathrm{MeHg}$ ) extracts (yellow bars) of feathers of three giant petrels (P2, P4, and P5). Error bars present $\pm 1 \mathrm{SD}$. Differences in values between total $\mathrm{Hg}$ and $\mathrm{MeHg}$ were $\leq 0.16 \%$, $\leq 0.03 \%$, $\leq 0.07 \%$ o $\leq 0.03 \%$, and $\leq 0.05 \%$ for $\delta^{202} \mathrm{Hg}, \Delta^{199} \mathrm{Hg}, \Delta \Delta^{201} \mathrm{Hg}, \Delta^{200} \mathrm{Hg}$, and $\Delta^{204} \mathrm{Hg}$, respectively. 


\section{Supplementary Tables}

Table S1. Isotopic values $( \pm 1 \mathrm{SD})$ of total mercury in giant petrel tissues rounded to the nearest hundredth.

\begin{tabular}{|c|c|c|c|c|c|c|c|c|c|c|c|c|c|c|c|c|c|c|c|}
\hline ID & Tissue & $\delta^{199} \mathrm{Hg}$ & \pm 1SD & $\delta^{200} \mathrm{Hg}$ & \pm 1SD & $\delta^{201} \mathrm{Hg}$ & \pm 1 SD & $\delta^{202} \mathrm{Hg}$ & \pm 1SD & $\delta^{204} \mathrm{Hg}$ & \pm 1 SD & $\Delta^{199} \mathrm{Hg}$ & \pm 1SD & $\Delta^{200} \mathrm{Hg}$ & \pm 1SD & $\Delta^{201} \mathbf{H g}$ & \pm 1 SD & $\Delta^{204} \mathrm{Hg}$ & \pm 1SD \\
\hline \multirow[t]{4}{*}{$\mathrm{P} 1$} & Feathers & 2.04 & 0.02 & 1.29 & 0.03 & 3.15 & 0.04 & 2.57 & 0.04 & 3.90 & 0.05 & 1.40 & 0.01 & 0.00 & 0.04 & 1.22 & 0.01 & 0.06 & 0.02 \\
\hline & Liver & 1.30 & 0.02 & -0.04 & 0.02 & 1.16 & 0.02 & 0.01 & 0.03 & 0.13 & 0.04 & 1.30 & 0.01 & -0.04 & 0.01 & 1.16 & 0.02 & 0.12 & 0.01 \\
\hline & Kidneys & 1.30 & 0.03 & -0.14 & 0.03 & 1.05 & 0.03 & -0.23 & 0.05 & -0.30 & 0.05 & 1.36 & 0.02 & -0.03 & 0.04 & 1.22 & 0.01 & 0.05 & 0.03 \\
\hline & Muscle & 1.06 & 0.03 & -0.63 & 0.03 & 0.37 & 0.02 & -1.19 & 0.03 & -1.70 & 0.03 & 1.36 & 0.03 & -0.04 & 0.02 & 1.26 & 0.01 & 0.07 & 0.03 \\
\hline \multirow[t]{4}{*}{ P2 } & Feathers & 2.28 & 0.02 & 1.29 & 0.02 & 3.31 & 0.02 & 2.57 & 0.03 & 3.83 & 0.05 & 1.64 & 0.02 & 0.00 & 0.01 & 1.38 & 0.01 & -0.01 & 0.02 \\
\hline & Liver & 1.43 & 0.02 & 0.02 & 0.02 & 1.33 & 0.03 & 0.05 & 0.03 & 0.13 & 0.05 & 1.42 & 0.01 & -0.01 & 0.00 & 1.29 & 0.01 & 0.05 & 0.02 \\
\hline & Kidneys & 1.59 & 0.03 & 0.05 & 0.03 & 1.47 & 0.02 & 0.15 & 0.02 & 0.27 & 0.04 & 1.55 & 0.02 & -0.02 & 0.02 & 1.35 & 0.01 & 0.05 & 0.02 \\
\hline & Muscle & 1.44 & 0.03 & -0.41 & 0.02 & 0.88 & 0.03 & -0.76 & 0.03 & -1.11 & 0.05 & 1.63 & 0.02 & -0.02 & 0.01 & 1.45 & 0.02 & 0.03 & 0.01 \\
\hline \multirow[t]{4}{*}{ P3 } & Feathers & 2.36 & 0.04 & 1.41 & 0.05 & 3.56 & 0.05 & 2.86 & 0.05 & 4.30 & 0.06 & 1.64 & 0.03 & -0.02 & 0.03 & 1.41 & 0.02 & 0.04 & 0.02 \\
\hline & Liver & 1.44 & 0.03 & -0.02 & 0.03 & 1.28 & 0.04 & 0.04 & 0.04 & 0.13 & 0.05 & 1.43 & 0.03 & -0.04 & 0.01 & 1.25 & 0.01 & 0.07 & 0.01 \\
\hline & Kidneys & 1.56 & 0.04 & 0.11 & 0.05 & 1.53 & 0.04 & 0.29 & 0.05 & 0.50 & 0.07 & 1.49 & 0.02 & -0.03 & 0.02 & 1.32 & 0.00 & 0.08 & 0.03 \\
\hline & Muscle & 1.59 & 0.02 & -0.33 & 0.03 & 1.08 & 0.02 & -0.57 & 0.02 & -0.74 & 0.03 & 1.73 & 0.01 & -0.05 & 0.02 & 1.51 & 0.01 & 0.11 & 0.05 \\
\hline \multirow[t]{4}{*}{ P4 } & Feathers & 2.44 & 0.04 & 1.38 & 0.03 & 3.62 & 0.02 & 2.80 & 0.03 & 4.18 & 0.04 & 1.74 & 0.03 & -0.03 & 0.01 & 1.51 & 0.01 & 0.00 & 0.06 \\
\hline & Liver & 1.43 & 0.04 & -0.06 & 0.03 & 1.20 & 0.02 & -0.10 & 0.04 & -0.10 & 0.03 & 1.45 & 0.03 & -0.01 & 0.01 & 1.28 & 0.01 & 0.05 & 0.05 \\
\hline & Kidneys & 1.47 & 0.03 & -0.07 & 0.05 & 1.22 & 0.03 & -0.16 & 0.05 & -0.23 & 0.07 & 1.52 & 0.01 & 0.02 & 0.03 & 1.34 & 0.02 & 0.01 & 0.04 \\
\hline & Muscle & 1.42 & 0.04 & -0.38 & 0.03 & 0.87 & 0.04 & -0.73 & 0.06 & -1.06 & 0.07 & 1.60 & 0.03 & -0.02 & 0.01 & 1.42 & 0.01 & 0.03 & 0.02 \\
\hline \multirow[t]{4}{*}{ P5 } & Feathers & 2.31 & 0.04 & 1.45 & 0.04 & 3.58 & 0.04 & 2.89 & 0.05 & 4.30 & 0.08 & 1.58 & 0.03 & 0.00 & 0.02 & 1.41 & 0.01 & -0.02 & 0.01 \\
\hline & Liver & 1.37 & 0.03 & 0.08 & 0.04 & 1.38 & 0.04 & 0.20 & 0.05 & 0.38 & 0.08 & 1.32 & 0.02 & -0.02 & 0.02 & 1.23 & 0.01 & 0.08 & 0.01 \\
\hline & Kidneys & 1.48 & 0.03 & 0.10 & 0.06 & 1.46 & 0.04 & 0.26 & 0.04 & 0.37 & 0.06 & 1.42 & 0.03 & -0.03 & 0.04 & 1.27 & 0.02 & -0.02 & 0.03 \\
\hline & Muscle & 1.78 & 0.02 & -0.36 & 0.02 & 0.77 & 0.03 & -0.74 & 0.04 & -1.07 & 0.06 & 1.97 & 0.02 & 0.01 & 0.01 & 1.33 & 0.00 & 0.03 & 0.01 \\
\hline P6 & Brain & 1.74 & 0.02 & 0.43 & 0.03 & 1.93 & 0.04 & 0.82 & 0.05 & 1.24 & 0.07 & 1.54 & 0.01 & 0.02 & 0.01 & 1.32 & 0.01 & 0.03 & 0.03 \\
\hline P7 & Brain & 1.82 & 0.02 & 0.98 & 0.03 & 2.64 & 0.04 & 1.96 & 0.05 & 3.00 & 0.07 & 1.33 & 0.02 & -0.01 & 0.01 & 1.16 & 0.01 & 0.06 & 0.03 \\
\hline P8 & Brain & 1.64 & 0.03 & 0.25 & 0.03 & 1.68 & 0.03 & 0.50 & 0.04 & 0.82 & 0.07 & 1.51 & 0.02 & 0.00 & 0.01 & 1.30 & 0.00 & 0.07 & 0.02 \\
\hline
\end{tabular}


Table S2. Chemical concentrations, fractions of $\mathrm{Hg}$ species by HR-XANES, and measured and calculated $\delta^{202} \mathrm{Hg}$ isotopic values $( \pm 1 \mathrm{SD})$ of giant petrel tissues rounded to the nearest hundredth ${ }^{\mathrm{a}}$.

\begin{tabular}{|c|c|c|c|c|c|c|c|}
\hline ID & Tissue & $\begin{array}{l}\mathrm{Hg}]_{\text {tot }} \\
\mathrm{mg} / \mathrm{kg}^{\mathrm{b}} \mathbf{d w}\end{array}$ & $f$ (MeHg) & $f\left(\mathrm{Hg}(\mathrm{Sec})_{4}\right)$ & $f$ (HgSe) & $\begin{array}{c}\delta^{202} \mathrm{Hg}_{t} \\
\% \text { oo }\end{array}$ & $\begin{array}{l}\delta^{202} \mathrm{Hg}_{\text {calc }} \mathrm{c} \\
\% \text { oo }\end{array}$ \\
\hline \multirow[t]{4}{*}{$\mathrm{P} 1$} & Feathers & 4.8 & $1.00 \pm 0.05$ & - & - & $2.57 \pm 0.04$ & $2.69 \pm 0.04$ \\
\hline & Liver & 226 & - & - & $1.00 \pm 0.05$ & $0.01 \pm 0.03$ & $0.18 \pm 0.02$ \\
\hline & Kidneys & 54.5 & - & $0.38 \pm 0.07$ & $0.62 \pm 0.07$ & $-0.23 \pm 0.05$ & $-0.41 \pm 0.04$ \\
\hline & Muscle & 26.6 & - & $0.72 \pm 0.07$ & $0.28 \pm 0.08$ & $-1.19 \pm 0.03$ & $-0.94 \pm 0.05$ \\
\hline \multirow[t]{4}{*}{ P2 } & Feathers & 26.2 & $1.00 \pm 0.05$ & - & - & $2.57 \pm 0.03$ & $2.69 \pm 0.04$ \\
\hline & Liver & 804 & - & - & $1.00 \pm 0.05$ & $0.05 \pm 0.03$ & $0.18 \pm 0.02$ \\
\hline & Kidneys & 37.7 & $0.07 \pm 0.03$ & $0.32 \pm 0.09$ & $0.61 \pm 0.08$ & $0.15 \pm 0.02$ & $-0.14 \pm 0.04$ \\
\hline & Muscle & 42.0 & - & $0.67 \pm 0.08$ & $0.33 \pm 0.08$ & $-0.76 \pm 0.03$ & $-0.86 \pm 0.05$ \\
\hline \multirow[t]{4}{*}{ P3 } & Feathers & 14.9 & $1.00 \pm 0.05$ & - & - & $2.86 \pm 0.05$ & $2.69 \pm 0.04$ \\
\hline & Liver & 293 & - & $0.09 \pm 0.06$ & $0.91 \pm 0.06$ & $0.04 \pm 0.04$ & $0.04 \pm 0.02$ \\
\hline & Kidneys & 40.9 & $0.12 \pm 0.03$ & $0.26 \pm 0.09$ & $0.62 \pm 0.07$ & $0.29 \pm 0.05$ & $0.08 \pm 0.03$ \\
\hline & Muscle & 21.8 & $0.07 \pm 0.03$ & $0.60 \pm 0.09$ & $0.33 \pm 0.09$ & $-0.57 \pm 0.02$ & $-0.57 \pm 0.05$ \\
\hline \multirow[t]{4}{*}{ P4 } & Feathers & 12.3 & $1.00 \pm 0.05$ & - & - & $2.80 \pm 0.03$ & $2.69 \pm 0.04$ \\
\hline & Liver & 1499 & - & $0.10 \pm 0.06$ & $0.90 \pm 0.06$ & $-0.10 \pm 0.04$ & $0.02 \pm 0.02$ \\
\hline & Kidneys & 414 & - & $0.29 \pm 0.07$ & $0.71 \pm 0.07$ & $-0.16 \pm 0.05$ & $-0.27 \pm 0.03$ \\
\hline & Muscle & 88.7 & - & $0.40 \pm 0.08$ & $0.60 \pm 0.08$ & $-0.73 \pm 0.06$ & $-0.44 \pm 0.04$ \\
\hline \multirow[t]{4}{*}{ P5 } & Feathers & 10.3 & $1.00 \pm 0.05$ & - & - & $2.89 \pm 0.05$ & $2.69 \pm 0.04$ \\
\hline & Liver & 170 & - & $0.06 \pm 0.06$ & $0.94 \pm 0.06$ & $0.20 \pm 0.05$ & $0.09 \pm 0.02$ \\
\hline & Kidneys & 9.84 & - & $0.52 \pm 0.09$ & $0.48 \pm 0.09$ & $0.26 \pm 0.04$ & $-0.63 \pm 0.04$ \\
\hline & Muscle & 2.87 & $0.11 \pm 0.05$ & $0.67 \pm 0.13$ & $0.22 \pm 0.11$ & $-0.74 \pm 0.04$ & $-0.58 \pm 0.05$ \\
\hline P6 & Brain & 2.8 & $0.40 \pm 0.06$ & $0.24 \pm 0.15$ & $0.36 \pm 0.13$ & $0.82 \pm 0.05$ & $0.81 \pm 0.04$ \\
\hline P7 & Brain & 1.6 & $0.83 \pm 0.05$ & $0.09 \pm 0.09$ & $0.08 \pm 0.08$ & $1.96 \pm 0.05$ & $2.12 \pm 0.04$ \\
\hline P8 & Brain & 13.2 & $0.13 \pm 0.05$ & $0.16 \pm 0.10$ & $0.71 \pm 0.08$ & $0.50 \pm 0.04$ & $0.26 \pm 0.03$ \\
\hline
\end{tabular}

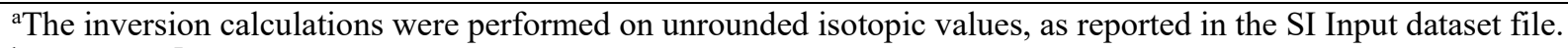

${ }^{b}$ From Ref. ${ }^{7}$.

${ }^{\mathrm{c} C a l c u l a t e d}$ value using Eq. 2 in main text, fractions of $\mathrm{Hg}$ species by HR-XANES, and $\delta^{202} \mathrm{MeHg}=2.69 \pm 0.04 \%$ o, $\delta^{202} \mathrm{Hg}(\mathrm{Sec}) 4=-1.37$

$\pm 0.06 \%$, and $\delta^{202} \mathrm{HgSe}=0.18 \pm 0.02$. 
Table S3. Isotopic values $( \pm 1 \mathrm{SD})$ of methylmercury $(\mathrm{MeHg})$ in giant petrel tissues.

\begin{tabular}{|c|c|c|c|c|c|c|c|c|c|c|c|c|c|c|c|c|c|c|c|}
\hline ID & Tissue & $\delta^{199} \mathrm{Hg}$ & \pm 1SD & $\delta^{200} \mathrm{Hg}$ & $\pm 1 \mathrm{SD}$ & $\delta^{201} \mathrm{Hg}$ & $\pm 1 \mathrm{SD}$ & $\delta^{202} \mathrm{Hg}$ & $\pm 1 \mathrm{SD}$ & $\delta^{204} \mathrm{Hg}$ & \pm 1 SD & $\Delta^{199} \mathrm{Hg}$ & \pm 1 SD & $\Delta^{200} \mathrm{Hg}$ & $\pm 1 \mathrm{SD}$ & $\Delta^{201} \mathrm{Hg}$ & \pm 1SD & $\Delta^{204} \mathbf{H g}$ & \pm 1 SD \\
\hline \multirow[t]{3}{*}{$\mathrm{P} 2$} & Feathers & 2.30 & 0.02 & 1.35 & 0.05 & 3.36 & 0.02 & 2.65 & 0.01 & 3.98 & 0.02 & 1.63 & 0.02 & 0.02 & 0.05 & 1.37 & 0.01 & 0.01 & 0.03 \\
\hline & Kidneys & 2.35 & 0.02 & 1.34 & 0.02 & 3.49 & 0.02 & 2.70 & 0.03 & 4.00 & 0.05 & 1.67 & 0.01 & -0.02 & 0.02 & 1.46 & 0.01 & -0.03 & 0.01 \\
\hline & Muscle & 2.43 & 0.02 & 1.40 & 0.03 & 3.60 & 0.03 & 2.78 & 0.03 & 4.19 & 0.02 & 1.72 & 0.02 & 0.00 & 0.01 & 1.51 & 0.02 & 0.04 & 0.05 \\
\hline \multirow[t]{2}{*}{ P3 } & Liver & 2.14 & 0.02 & 0.96 & 0.01 & 2.87 & 0.03 & 1.87 & 0.03 & 2.81 & 0.02 & 1.67 & 0.02 & 0.02 & 0.01 & 1.47 & 0.02 & 0.02 & 0.06 \\
\hline & Muscle & 2.15 & 0.01 & 1.04 & 0.03 & 3.02 & 0.01 & 2.07 & 0.03 & 3.11 & 0.03 & 1.63 & 0.01 & 0.00 & 0.02 & 1.46 & 0.02 & 0.01 & 0.02 \\
\hline \multirow[t]{2}{*}{ P4 } & Feathers & 2.47 & 0.01 & 1.44 & 0.03 & 3.61 & 0.05 & 2.87 & 0.03 & 4.35 & 0.02 & 1.75 & 0.02 & 0.00 & 0.02 & 1.45 & 0.03 & 0.06 & 0.05 \\
\hline & Muscle & 2.01 & 0.01 & 0.43 & 0.02 & 2.21 & 0.01 & 0.90 & 0.04 & 1.30 & 0.06 & 1.79 & 0.02 & -0.02 & 0.01 & 1.53 & 0.03 & -0.05 & 0.02 \\
\hline P5 & Feathers & 2.38 & 0.02 & 1.53 & 0.02 & 3.68 & 0.02 & 3.05 & 0.03 & 4.54 & 0.05 & 1.61 & 0.01 & -0.01 & 0.02 & 1.38 & 0.01 & -0.01 & 0.02 \\
\hline P8 & Brain & 2.22 & 0.02 & 1.28 & 0.03 & 3.28 & 0.03 & 2.58 & 0.04 & 3.82 & 0.03 & 1.57 & 0.02 & -0.01 & 0.01 & 1.33 & 0.02 & -0.04 & 0.04 \\
\hline
\end{tabular}

Table S4. Isotope values used to assess the mass-independent fractionation (MIF) in giant petrels.

\begin{tabular}{|c|c|c|c|c|c|c|c|c|c|}
\hline ID & $\begin{array}{c}\Delta^{199} \mathrm{Hg}_{\text {initial }}{ }^{\mathrm{a}} \\
\% \%\end{array}$ & $\begin{array}{l}\text { Samples for } \\
\Delta^{199} \mathbf{H g}_{\text {initial }}{ }^{b}\end{array}$ & $\begin{array}{c}\Delta_{\%}^{199} \mathrm{HgSe}^{\mathrm{c}} \\
\%\end{array}$ & $\begin{array}{c}\text { Diff. in } \\
\Delta^{199} \mathrm{Hg}^{\mathrm{d}} \\
\% \%\end{array}$ & $\begin{array}{c}\Delta^{201} \mathbf{H g}_{\text {initial }}{ }^{\mathrm{a}} \\
\% \text { oo }\end{array}$ & $\begin{array}{l}\text { Samples for } \\
\Delta^{201} \mathrm{Hg}_{\text {initial }} \mathrm{b}\end{array}$ & $\begin{array}{c}\Delta_{\%}^{201} \mathrm{HgSe}^{\mathrm{b}} \\
\%\end{array}$ & $\begin{array}{c}\text { Diff. in } \\
\Delta^{201} \mathbf{H g}^{\mathrm{d}} \\
\%\end{array}$ & $\begin{array}{l}\text { Diff. } \Delta^{199} \mathrm{Hg} / \\
\text { Diff. } \Delta^{201} \mathrm{Hg}\end{array}$ \\
\hline $\mathrm{P} 1$ & $1.40 \pm 0.01$ & $\Delta^{199} \mathrm{Hg}_{\mathrm{f}}$ & $1.30 \pm 0.01$ & $-0.10 \pm 0.01$ & $1.22 \pm 0.01$ & $\Delta^{201} \mathrm{Hg}_{\mathrm{f}}$ & $1.16 \pm 0.02$ & $-0.06 \pm 0.02$ & 1.67 \\
\hline $\mathrm{P} 2$ & $1.66 \pm 0.04$ & $\begin{array}{l}\Delta^{199} \mathrm{MeHg}_{\mathrm{f}}, \\
\Delta^{199} \mathrm{MeHg}_{\mathrm{k}} \\
\Delta^{199} \mathrm{MeHg}_{\mathrm{m}}\end{array}$ & $1.42 \pm 0.01$ & $-0.24 \pm 0.03$ & $1.43 \pm 0.07$ & $\begin{array}{c}\Delta^{201} \mathrm{MeHg}_{\mathrm{f}}, \\
\Delta^{201} \mathrm{MeHg}_{\mathrm{k}} \\
\Delta^{201} \mathrm{MeHg}_{\mathrm{m}}\end{array}$ & $1.29 \pm 0.01$ & $-0.14 \pm 0.05$ & 1.71 \\
\hline P3 & $1.65 \pm 0.02$ & $\begin{array}{c}\Delta^{199} \mathrm{Hg}_{\mathrm{f},} \Delta^{199} \mathrm{MeHg}_{\mathrm{l}} \\
\Delta^{199} \mathrm{MeHg}_{\mathrm{m}}\end{array}$ & $1.43 \pm 0.03$ & $-0.22 \pm 0.02$ & $1.45 \pm 0.03$ & $\begin{array}{c}\Delta^{201} \mathrm{Hg}_{\mathrm{f},} \Delta^{201} \mathrm{MeHg}_{\mathrm{l}}, \\
\Delta^{201} \mathrm{MeHg}_{\mathrm{m}}\end{array}$ & $1.25 \pm 0.01$ & $-0.20 \pm 0.02$ & 1.10 \\
\hline P4 & $1.77 \pm 0.03$ & $\begin{array}{l}\Delta^{199} \mathrm{MeHg}_{\mathrm{f}} \\
\Delta^{199} \mathrm{MeHg}_{\mathrm{m}}\end{array}$ & $1.45 \pm 0.03$ & $-0.32 \pm 0.03$ & $1.49 \pm 0.06$ & $\begin{array}{l}\Delta^{201} \mathrm{MeHg}_{\mathrm{f}} \\
\Delta^{201} \mathrm{MeHg}_{\mathrm{m}}\end{array}$ & $1.28 \pm 0.01$ & $-0.21 \pm 0.04$ & 1.52 \\
\hline P5 & $1.61 \pm 0.01$ & $\Delta^{199} \mathrm{MeHg}_{\mathrm{f}}$ & $1.32 \pm 0.02$ & $-0.29 \pm 0.02$ & $1.38 \pm 0.01$ & $\Delta^{201} \mathrm{MeHg}_{\mathrm{f}}$ & $1.23 \pm 0.01$ & $-0.15 \pm 0.01$ & 1.93 \\
\hline
\end{tabular}

${ }^{a}$ Uncertainties are $\pm 1 \mathrm{SD}$ of individual measurements or $\pm 1 \mathrm{SD}$ of mean of multiple measurements.

${ }^{\mathrm{b}} \Delta^{\mathrm{XxX}} \mathrm{Hg}_{\text {initial }}$ are values of total $\mathrm{Hg}$ digests of feathers, and $\Delta^{\mathrm{XXX}} \mathrm{MeHg}$ are values of the MeHg extracted from feathers or tissues. Subscripts identify tissue type (f, feather; $\mathrm{k}$, kidneys; $\mathrm{m}$, muscle; 1 , liver).

${ }^{c}$ Values are of liver tissues that are predominantly $\mathrm{HgSe}(f(\mathrm{HgSe})>0.90$; see Table $\mathrm{S} 2$ and Figure 1 in main text $)$.

${ }^{\mathrm{d}}$ The difference between $\Delta^{199} \mathrm{MeHg}$ and $\Delta^{199} \mathrm{HgSe}$ or $\Delta^{201} \mathrm{MeHg}$ and $\Delta^{201} \mathrm{HgSe}$. 
Table S5. Measured mercury isotopic values of certified reference materials (CRMs) and standards and references these data were compared against.

\begin{tabular}{|c|c|c|c|c|c|c|c|c|c|c|c|c|}
\hline CRM & $\begin{array}{l}\text { Fraction } \\
\text { of } \mathrm{Hg}\end{array}$ & $\begin{array}{l}\delta^{199} \mathrm{Hg} \\
( \pm 2 \mathrm{SD})\end{array}$ & $\begin{array}{l}\delta^{200} \mathrm{Hg} \\
( \pm 2 \mathrm{SD})\end{array}$ & $\begin{array}{l}\delta^{201} \mathrm{Hg} \\
( \pm 2 \mathrm{SD})\end{array}$ & $\begin{array}{l}\delta^{202} \mathrm{Hg} \\
( \pm 2 \mathrm{SD})\end{array}$ & $\begin{array}{l}\delta^{204} \mathrm{Hg} \\
( \pm 2 \mathrm{SD})\end{array}$ & $\begin{array}{l}\Delta^{199} \mathrm{Hg} \\
\text { ( } \pm 2 \mathrm{SD})\end{array}$ & $\begin{array}{l}\Delta^{200} \mathrm{Hg} \\
( \pm 2 \mathrm{SD})\end{array}$ & $\begin{array}{l}\Delta^{201} \mathrm{Hg} \\
( \pm 2 \mathrm{SD})\end{array}$ & $\begin{array}{l}\Delta^{204} \mathrm{Hg} \\
( \pm 2 \mathrm{SD})\end{array}$ & $n$ & Ref. \\
\hline DOLT-2 & Total Hg & $\begin{array}{l}0.60 \\
(0.09)\end{array}$ & $\begin{array}{l}-0.22 \\
(0.09)\end{array}$ & $\begin{array}{l}0.25 \\
(0.09)\end{array}$ & $\begin{array}{l}-0.49 \\
(0.08)\end{array}$ & $\begin{array}{l}-0.72 \\
(0.10)\end{array}$ & $\begin{array}{l}0.73 \\
(0.07)\end{array}$ & $\begin{array}{l}0.03 \\
(0.05)\end{array}$ & $\begin{array}{l}0.62 \\
(0.03)\end{array}$ & $\begin{array}{l}0.01 \\
(0.03)\end{array}$ & 3 & Rosera et al. ${ }^{8}$ \\
\hline DOLT-2 & $\mathrm{MeHg}$ & $\begin{array}{l}0.98 \\
(0.06)\end{array}$ & $\begin{array}{l}0.10 \\
(0.06)\end{array}$ & $\begin{array}{l}0.91 \\
(0.08)\end{array}$ & $\begin{array}{l}0.12 \\
(0.04)\end{array}$ & $\begin{array}{l}0.11 \\
(0.01)\end{array}$ & $\begin{array}{l}0.95 \\
(0.05)\end{array}$ & $\begin{array}{l}0.04 \\
(0.03)\end{array}$ & $\begin{array}{l}0.82 \\
(0.05)\end{array}$ & $\begin{array}{l}-0.07 \\
(0.06)\end{array}$ & 2 & Rosera et al. ${ }^{8}$ \\
\hline $\begin{array}{l}\text { UM } \\
\text { Almadén }{ }^{\mathrm{a}}\end{array}$ & Total Hg & $\begin{array}{l}-0.15 \\
(0.04)\end{array}$ & $\begin{array}{l}-0.26 \\
(0.05)\end{array}$ & $\begin{array}{l}-0.45 \\
(0.05)\end{array}$ & $\begin{array}{l}-0.55 \\
(0.06)\end{array}$ & $\begin{array}{l}-0.83 \\
(0.12)\end{array}$ & $\begin{array}{l}-0.01 \\
(0.04)\end{array}$ & $\begin{array}{l}0.01 \\
(0.04)\end{array}$ & $\begin{array}{l}-0.03 \\
(0.03)\end{array}$ & $\begin{array}{l}0.01 \\
(0.06)\end{array}$ & 14 & NIST $^{9}$ \\
\hline
\end{tabular}

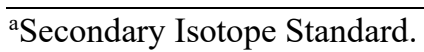




\section{Supplementary references}

(1) Poulin, B. A.; Janssen, S. E.; Rosera, T. J.; Krabbenhoft, D. P.; Eagles-Smith, C. A.; Ackerman, J. T.; Stewart, A. R.; Kim, E.; Baumann, Z.; Kim, J. H.; Manceau, A. Isotope fractionation from in vivo methylmercury detoxification in waterbirds. ACS Earth Space Chem. 2021, 990-997.

(2) Wiederhold, J. G.; Cramer, C. J.; Daniel, K.; Infante, I.; Bourdon, B.; Kretzschmar, R. Equilibrium mercury isotope fractionation between dissolved $\mathrm{Hg}(\mathrm{II})$ species and thiol-bound $\mathrm{Hg}$. Environ. Sci. Technol. 2010, 44, 4191-4197.

(3) Bergquist, B. A.; Blum, J. D. Mass-dependent and -independent fractionation of $\mathrm{Hg}$ isotopes by photoreduction in aquatic systems. Science 2007, 318, 417-420.

(4) Ghosh, S.; Schauble, E. A.; Couloume, G. L.; Blum, J. D.; Bergquist, B. A. Estimation of nuclear volume dependent fractionation of mercury isotopes in equilibrium liquid-vapor evaporation experiments. Chem. Geol. 2013, 336, 5-12.

(5) Li, M. L.; Juang, C. A.; Ewald, J. D.; Yin, R. S.; Mikkelsen, B.; Krabbenhoft, D. P.; Balcom, P. H.; Dassuncao, C.; Sunderland, E. M. Selenium and stable mercury isotopes provide new insights into mercury toxicokinetics in pilot whales. Sci. Tot. Environ. 2020, 710, n 136325.

(6) Renedo, M.; Pedrero, Z.; Amouroux, D.; Cherel, Y.; Bustamante, P. Mercury isotopes of key tissues document mercury metabolic processes in seabirds. Chemosphere 2021, 263, $\mathrm{n}^{\circ} 127777$.

(7) Manceau, A.; Gaillot, A. C.; Glatzel, P.; Cherel, Y.; Bustamante, P. In vivo formation of HgSe nanoparticles and Hg-tetraselenolate complex from methylmercury in seabird - Implications for the Hg-Se antagonism. Environ. Sci. Technol. 2021, 55, 1515-1526.

(8) Rosera, T. J.; Janssen, S. E.; Tate, M. T.; Lepak, R. F.; Ogorek, J. M.; DeWild, J. F.; Babiarz, C. L.; Krabbenhoft, D. P.; Hurley, J. P. Isolation of methylmercury using distillation and anion-exchange chromatography for isotopic analyses in natural matrices. Anal. Bioanal. Chem. 2020, 412, 681-690.

(9) National Institute of Standards and Technology (NIST) Report of investigation: RM8610 mercury isotopes in UM Almadén monoelemental secondary standard. 2017, https://wwws.nist.gov/srmors/certificates/8610.pdf.

(10) Poulin, B. A., Janssen, S. E., and Rosera, T. J., 2021, Mercury and Methylmercury Stable Isotope Measurements in Giant Petrels: U.S. Geological Survey Data Release, https://doi.org/10.5066/P9UEG9Q1. 